\title{
The role of antiviral treatment in curbing the COVID-19 pandemic: a modeling study.
}

\author{
Laura Matrajt, ${ }^{1 *}$ Elizabeth R. Brown ${ }^{1,2}$, Dobromir Dimitrov ${ }^{1,3}$, Holly Janes ${ }^{1}$ \\ ${ }^{1}$ Vaccine and Infectious Disease Division, Fred Hutchinson Cancer Research Center, Seattle, WA, USA \\ ${ }^{2}$ Department of Biostatistics, University of Washington, Seattle, WA, USA \\ ${ }^{3}$ Department of Applied Mathematics, University of Washington, Seattle, WA, USA \\ *To whom correspondence should be addressed; E-mail: laurama@ fredhutch.org
}

Classification: Biological Sciences, Medical Sciences.

Keywords: antiviral, COVID-19, SARS-CoV-2, mathematical model 


\begin{abstract}
Despite the development of safe and effective vaccines, effective treatments for COVID-19 disease are still desperately needed. Recently, two antiviral drugs have shown to be effective in reducing hospitalizations in clinical trials. In the present work, we use an agent-based mathematical model to assess the potential population impact of the use of antiviral treatments in four countries, corresponding to four current levels of vaccination coverage: Kenya, Mexico, United States (US) and Belgium, with $1.5,38,57$ and $74 \%$ of their populations vaccinated. For each location, we varied antiviral coverage and antiviral effect in reducing viral load $(25,50,75$ or $100 \%$ reduction). Irrespective of location, widespread antiviral treatment of symptomatic infections ( $\geq 50 \%$ coverage) is expected to prevent the majority of COVID-19 deaths. Furthermore, even treating $20 \%$ of adult symptomatic infections, is expected to reduce mortality by a third in all countries, irrespective of the assumed treatment efficacy in reducing viral load. Our results suggest that early antiviral treatment is needed to mitigate transmission, with early treatment (within two days of symptoms) preventing 50\% more infections compared to late treatment (started on days 3 to 5 after developing symptoms). Our results highlight the synergistic effect of vaccination and antiviral treatment: as vaccination rate increased, antiviral treatment had a bigger impact on overall transmission. These results suggest that antiviral treatments can become a strategic tool that, in combination with vaccination, can significantly control SASRS-CoV-2 transmission and reduce COVID-19 hospitalizations and deaths.
\end{abstract}

\title{
Significance
}

Several antiviral drugs have shown to be highly effective in reducing hospitalizations in clinical trials. We used a mathematical model to assess the potential impact of antiviral treatments in four different countries with vastly different proportions of vaccinated individuals (Kenya, Mexico, United States and Belgium). Irrespective of location, widespread antiviral use in adult symptomatic infections can prevent most deaths. Furthermore, a third of deaths could be averted by treating only $20 \%$ of adult symptomatic infections. We identified a synergistic effect of antiviral treatment and vaccination by which countries with larger proportion of their population vaccinated benefited more from antiviral treatments. Our results show that antiviral treatments can be an extremely useful tool to reduce COVID-19 deaths and curtail SARS-CoV-2 transmission.

\section{Introduction}

With over 5 million deaths worldwide [1], the COVID-19 pandemic has proven difficult to contain. Despite the development of many safe and effective vaccines, controlling SARS-CoV-2 transmission has shown to be elusive for several reasons, including vaccine supply shortages in low- and middle-income countries [2], vaccine hesitancy [3], and the emergence of new variants [4]. Indeed, the delta variant, that emerged in the spring-summer of 2021, quickly became the predominant strain in most of the world [5] and has caused large epidemic outbreaks, even in highly vaccinated regions [1]. Rapidly producing such COVID19 vaccines has been an amazing scientific endeavor, but effective tools to treat COVID-19 disease are still desperately needed. Currently, there is only one antiviral drug (remdesivir) and one monoclonal antibody (REGEN-COV) approved for COVID19 treatment in the United States (US). These therapies can be highly effective but they must be administered intravenously or by subcutaneous injection and might be costly, which makes their widespread use, especially in low- and middle-income countries, difficult to implement at the moment. Two potential antiviral oral treatments against COVID-19 are in testing 
medRxiv preprint doi: https://doi.org/10.1101/2021.11.10.21266139; this version posted November 11, 2021. The copyright holder for this

preprint (which was not certified by peer review) is the author/funder, who has granted medRxiv a license to display the preprint in perpetuity.

It is made available under a CC-BY-NC-ND 4.0 International license .

phase, and others are in development [6]. Recently, molnupiravir, an antiviral oral treatment currently in phase 3 clinical trial, was shown to reduce hospitalizations by approximately 50\% [7] when taken within five days from symptoms onset. This prompted its manufacturer to request Emergency Use Approval (EUA) from the Federal Drug Administration (FDA) [8]. Another oral antiviral treatment, PAXLOVID, was found to reduce hospitalizations and deaths by $89 \%$ in a phase 3 clinical trial interim analysis, and its manufacturer will request EUA as soon as possible [9]. Similarly, remdesivir was found to reduce hospitalizations by $87 \%$ when taken shortly after symptom onset and its manufacturer is working on a oral version of the drug $[10,11]$. Further, earlier studies have shown that these antiviral treatments significantly reduced the amount of infectious virus in treated individuals [6]. Experience with other infectious diseases, such as influenza and HIV, has shown that potent antiviral treatments can be an effective means of prevention and epidemic control [12, 13]. Hence, the advent of effective antiviral drugs raises the possibility that in treating infected individuals we may be prevented onward transmission (indirect population benefit) while also protecting the treated person from severe disease (direct benefit).

In this work, we use an agent-based mathematical model to evaluate the potential population impact of widespread use of antiviral treatments reducing hospitalization risk and viral load. We explored the use of antiviral treatments in four different countries (Kenya, Mexico, United States (US) and Belgium) with vastly different proportions of vaccinated individuals (1.5, 38, 57 and $74 \%$ respectively) and showed that the synergistic use of vaccine and antiviral treatments can significantly reduce the burden of COVID-19 and help restore normalcy.

\section{Results}

Briefly, we used COVASIM [14], a previously developed agent-based model of SARS-CoV-2 spread. Our model simulates a population of 500,000 people interacting through a network over the course of a 6 month time horizon, where each individual in the population is an agent. Every day, individuals get in contact with others in four possible locations: "home", "school", "work" or "community". At a given point in time, individuals can be susceptible, infected asymptomatic, pre-symptomatic or symptomatic, and recovered. Symptomatic infected individuals can develop a mild, severe or critical infection after symptoms onset. Age-specific proportions of infections are assumed to progress without developing symptoms being $30 \%$ less infectious than symptomatic ones (Table S1). We also assumed that $40 \%$ of the population has been infected in previous epidemic waves and protected from re-infection but scenarios with 20 and $60 \%$ previously infected were explored as sensitivity analyses (see Methods for full details). We simulated synthetic populations of equal size at four different locations: Kenya, Mexico, US and Belgium. For each location, the model uses country-specific demographics to inform population structure and households. For Mexico, the US and Belgium, we used country- and age-specific vaccination rates as of October 12th, 2021 [15-17]. 
As of this date, Kenya has fully vaccinated only $1.5 \%$ of its population, targeting front-line health workers, teachers, police and military, so we distributed its vaccine randomly among all adults $[2,18]$. For each country, we assumed that no further vaccine doses would be delivered over the study duration (6 months).

In line with results from clinical trials [6], we assumed that the antiviral treatment would have two primary effects. First, an antiviral effect on viral load, denoted by AVE, by which it reduces the viral load of those infected with SARS-CoV-2 and under treatment. We considered reductions of 25,5075 or $100 \%$ on each day post-infection. Because in our model, viral load linearly correlates with infectiousness, these assumptions resulted in equal reduction in the transmissibility. Second, the antiviral treatment reduces the rate of hospitalization of symptomatic infected individuals. Based on recent results from phase 3 clinical trials, we assumed that this reduction, denoted by $\mathrm{AV}_{\mathrm{H}}$, was $50 \%$ (main results) or $80 \%$ (sensitivity analysis) $[7,9,10]$. Because antiviral treatment has not been tested yet as a prophylactic therapy, so we limited our analysis to interventions mimicking the conditions under which the antiviral products were tested in clinical trials: we assumed that antiviral treatment would be given to adult symptomatically infected individuals (denoted below as eligible symptomatic infections) within five days from symptoms onset. We explored scenarios with treatment initiated within five days, within two days or between days 3 and 5 from symptoms onset, separately to study the impact of treatment timing on the results. We also varied treatment coverage ranging from 10 to $100 \%$ of eligible symptomatic infections. Throughout the text, we present the median percentage deaths and infections averted compared to base-case scenario assuming that existing non-pharmaceutical measures remain in place for the next 6 months without additional vaccination across 100 simulations. Cumulative deaths and infections (and respective confidence bounds) are presented in the Supplemental Material.

Widespread use of antiviral treatment can avert large numbers of deaths. For all the countries considered, under the best-case scenario assuming that all symptomatic infections were treated (100\% coverage) with complete reduction of transmission after treatment (100\% AVE), the model projected 59, 80, 82 and $90 \%$ fewer deaths compared to no antiviral use for Kenya, Mexico, the US and Belgium respectively. Covering only $50 \%$ of eligible symptomatic infections averted the majority of deaths, in all countries irrespective of AVE (Fig.1). Even a modest coverage (20\% of symptomatic infections) and a very low antiviral effect on viral load $(\mathrm{AVE}=25 \%)$, reduced mortality in all simulated countries by more than a third $(34,34,36$ and $42 \%$ for Kenya, Mexico, the US and Belgium respectively). Importantly, increasing coverage beyond $60 \%$ of eligible symptomatic infections for a fixed AVE, only marginally improved the impact on mortality. For example, assuming AVE = $50 \%$, increasing coverage from 60 to $80 \%$ of eligible symptomatic infections resulted in an additional $2 \%$ deaths averted for all countries (Fig.1). 
medRxiv preprint doi: https://doi.org/10.1101/2021.11.10.21266139; this version posted November 11, 2021. The copyright holder for this

preprint (which was not certified by peer review) is the author/funder, who has granted medRxiv a license to display the preprint in perpetuity.

It is made available under a CC-BY-NC-ND 4.0 International license .

The antiviral effect on viral load (AVE) influenced more the number of deaths averted in highly vaccinated countries: for Belgium, US, and Mexico, the increase of AVE from $25 \%$ to $100 \%$ averted $\sim 26 \%$ more deaths. In contrast, for Kenya, this increase resulted in only $12 \%$ more deaths averted (Fig.1).

Synergistic effect of antiviral treatment and vaccine can control SARS-CoV-2 transmission. When evaluating the impact on transmission, we found clear synergy of combining antiviral treatment and vaccination. Kenya, the only setting with very low vaccination coverage, saw a smaller impact from the use of antiviral treatment in overall transmission with only $24 \%$ of infections averted in the most optimistic scenario ( $\mathrm{AVE}=100 \%$ and $100 \%$ antiviral coverage). In contrast, under the same scenario, countries with moderate or high vaccination had over 50\% of their infections averted (58, 63 and $85 \%$ for Mexico, the US and Belgium respectively). As the vaccination rate increased, antiviral treatment had a bigger effect: assuming that the antiviral treatment reduced viral load by $50 \%$, treating $20 \%$ of symptomatic infections averted $4,9,12$ and $24 \%$ of the overall infections in Kenya, Mexico, US and Belgium respectively. Indeed with very limited vaccine supply, the effective reproductive number in Kenya is much larger than in the other countries, resulting in epidemics that are more difficult to control (Figs. 2 and 3). As expected, the antiviral effect on viral load played a bigger role in controlling SARS-CoV-2 transmission. With a low AVE (25\%), a very limited number of infections were averted, irrespective of coverage or location, with a maximum of 4, 9, 12 and $26 \%$ of infections averted in Kenya, Mexico, US and Belgium respectively. In contrast, with high AVE (75\%), then a maximum of 15, 36, 44 and 73\% of infections were averted in Kenya, Mexico, US and Belgium respectively. Note that, for $\mathrm{AVE}=25,50$ or $75 \%$, the number of infections averted plateaued for medium and high antiviral treatment coverage. For example, in the US, treating $30 \%$ of eligible symptomatic infections with an antiviral treatment with $\mathrm{AVE}=50 \%$ averted $16 \%$ of infections, and treating an additional $20 \%$ of eligible symptomatic infections (50\% coverage) resulted in only $5 \%$ more infections averted (Fig. 2). This was due to two factors: first, only symptomatic cases were treated while asymptomatic infections continued the chain of transmission. Second, antiviral treatment was given within the first five days after symptoms onset, but in our model symptomatic individuals are most infectious in pre-symptomatic phase and within two days from symptoms onset.

Early treatment is needed to mitigate transmission. We analyzed the difference between early and late treatment by considering treating eligible symptomatic infections within the first two days of symptoms or alternatively between days 3 and 5 after symptom onset. At low antiviral coverage, irrespective of the value of AVE, there was little difference between early or late treatment, as both resulted in very low numbers of subsequent infections averted. If $10 \%$ of the adult symptomatic 
medRxiv preprint doi: https://doi.org/10.1101/2021.11.10.21266139; this version posted November 11, 2021. The copyright holder for this

preprint (which was not certified by peer review) is the author/funder, who has granted medRxiv a license to display the preprint in perpetuity.

It is made available under a CC-BY-NC-ND 4.0 International license .

infections were treated, the difference between early and late treatment was less than $5 \%$ of infections, regardless the value of AVE or location. However, as antiviral coverage and AVE increased, the difference between early and late treatment became more important, Fig. 4. Assuming AVE $=50 \%$ and treating at least $50 \%$ of symptomatic infections early prevented $50 \%$ more subsequent infections than late treatment for all countries. Early treatment was more important for countries with moderate or low vaccination coverage, but the importance of the treatment timing decreased if larger proportion of the population was vaccinated. For Kenya and Mexico, early treatment prevented roughly twice as many subsequent infections compared to late treatment (AVE $\geq 75 \% \geq 80 \%$ coverage), but there was a maximum difference of $67 \%$ more infections averted between early and late treatment in Belgium (AVE=50\%, 100\% coverage), Fig. 4.

\section{Sensitivity analysis}

Increased antiviral reduction in hospitalization, $\mathbf{A} \mathbf{V}_{\mathbf{H}}=\mathbf{8 0 \%}$. As expected, an antiviral treatment which reduces the hospitalization risk of symptomatically infected by $80 \%$ averted more deaths than our main scenario $\left(\right.$ with $\left.\mathrm{AV}_{\mathrm{H}}=50 \%\right)$ (Fig. S3). A modest coverage of $20 \%$ of eligible symptomatic infections resulted in over $50 \%$ of the deaths averted for all four countries, irrespective of the value of AVE.

Increase or decreased pre-existing immunity. Different places, even within a country, have experienced the COVID-19 pandemic in different ways, depending on local non-pharmaceutical interventions and population demographics [19, 20]. Hence, we considered the effect of pre-existing immunity on our results, assuming a lower (20\%) or higher (60\%) fraction of the population with prior infection. Low pre-existing immunity resulted in big epidemic waves and lower proportions of deaths averted with antiviral treatment compared to the main results for all countries, all coverages and all AVEs. For instance, we projected 5, 16, 12 and 11\% fewer deaths averted in Kenya, Mexico, US, and Belgium respectively under this scenario with $100 \%$ coverage and AVE $=100 \%$, Figs. S4, S5, and S6). In contrast, assuming that a higher proportion of the population had been previously infected had mixed effects on the results: for Kenya, we still observed a big epidemic wave, but having a larger proportion of the population immune enhanced the effects of the antiviral treatment, reducing $8 \%$ more deaths compared to the main scenario. For Mexico, US, and Belgium, we did not observed significant epidemic waves (Figs. S5 and S7).

Decrease in asymptomatic infectiousness The relative infectivity of asymptomatic individuals remains uncertain [21]. We explored scenarios in which asymptomatic individuals are 50\% less infectious than symptomatic ones. Our results were not sensitive to this parameter, Fig. S8. 
medRxiv preprint doi: https://doi.org/10.1101/2021.11.10.21266139; this version posted November 11, 2021. The copyright holder for this

preprint (which was not certified by peer review) is the author/funder, who has granted medRxiv a license to display the preprint in perpetuity.

It is made available under a CC-BY-NC-ND 4.0 International license .

\section{Discussion}

In the present work we analyzed the potential population impact of antiviral treatments for reducing SARS-CoV-2 transmission and COVID-19 related hospitalizations and deaths. We considered four equal-sized populations from four different countries (Kenya, Mexico, US and Belgium), representing different population structures and vaccination coverage.

Despite the existence of effective vaccines thousands of people continue to suffer from severe COVID infections around the world due to issues with supply, hesitancy and logistics. This highlights the need of effective and affordable treatment options. The Medicines Patent Pool and Merck (the manufacturers of molnupiravir) recently announced a license agreement to facilitate global access for molnupiravir [22]. Other antiviral treatments, with over $80 \%$ efficacy reducing hospitalizations, might become available very soon [9]. Our results suggest that irrespective of country and the AVE, widespread antiviral treatment (targeting $\geq 50 \%$ of adult symptomatic infections) could prevent the majority of deaths. While it is challenging to identify and test symptomatic infections, our analysis shows that treating even a small fraction of symptomatic infections can still have a large impact on the expected number of COVID deaths. Indeed, treating only $20 \%$ of symptomatic infections averted over a third of deaths in all countries (assuming antiviral reduced viral load by 25\%). We demonstrated that effective antiviral treatments could prevent a much larger number of deaths, even if not taken immediately after symptoms onset but within 5 days following it. This highlights the need to better use and promote the use of currently available and potential new antiviral treatments. More importantly, our model suggests that there is a synergistic effect of combining antiviral treatment and vaccination: countries with larger proportion of their populations vaccinated are expected to benefit more from adding antiviral treatment. This emphasizes the need of continuous effort to improve vaccination coverage especially in settings where it is extremely low. Finally, our simulations showed that early treatment, when viral load is highest, is important for mitigating transmission and could be used as a prevention tool. This is in agreement with previous work [23-27] that has shown the potential use of antiviral therapies to reduce COVID-19 related mortality.

Our model, like all mathematical models, is subject to several limitations. We did not consider the development of antiviral resistance, yet it is possible that if antiviral treatments are widely used, resistance could rapidly develop. We analyzed the use of antiviral treatment in symptomatic individuals, and did not explore its use in asymptomatic infections or as a prophylaxis. Further, we assumed that an antiviral effect reducing viral load was independent of when treatment was started (as long as it started within the first five days of treatment). In reality, it is possible that antiviral treatments might different effects in reducing viral load at different times, e.g. reducing peak viral load early on but having only a modest effect as time goes by. For simplicity, we did not include waning immunity, but there are increasing reports that both vaccine- 
medRxiv preprint doi: https://doi.org/10.1101/2021.11.10.21266139; this version posted November 11, 2021. The copyright holder for this

preprint (which was not certified by peer review) is the author/funder, who has granted medRxiv a license to display the preprint in perpetuity.

It is made available under a CC-BY-NC-ND 4.0 International license .

induced and infection-induced immunity might wane in a few months. We assumed that the vaccine had no effect in reducing infectiousness, but if vaccination does reduce infectiousness then the synergy between antiviral and vaccine might be less than reported here. We assumed no further vaccination during the period of our analysis, which corresponds to the current situation in most middle- and high-vaccinated countries, where the adult population who are willing to be vaccinated has already been immunized. Nevertheless, the recent approval of the Pfizer vaccine for children aged 5 to 11 years old will change that, immediately increasing the overall proportion of the population vaccinated in high-income countries, hence reducing further on-going transmission. In addition, WHO recently released an ambitious plan to vaccinate $40 \%$ of the population in every country by the end of 2021 [28]. While it is impossible to predict when and how different populations will become vaccinated and the percentage of pre-existing immunity in each population, we believe that the scenarios that we have considered here, with different combinations of vaccination coverage and proportions of the population with preexisting infection-induced immunity, are sufficient to capture the potential population-level effect of the potential use of antiviral treatment on transmission and COVID-19-related severe outcomes.

Taken together, our results suggest that antiviral treatment can be an extremely useful tool to reduce COVID-19 related deaths and to alleviate the COVID-19 burden on overwhelmed and exhausted healthcare systems, but that it cannot be a replacement for vaccination. Rather, the standard must be for all countries and all communities to achieve high rates of vaccination, wherein use of antiviral treatment can potentially achieve a more significant impact mitigating transmission.

\section{Methods}

\section{Main model}

We adapted a previously developed agent-based transmission model, COVASIM [14]. Namely, we extended the model to include the use of antiviral treatments in the population. We briefly describe here the main features of this model (as were used in the present work) and we describe in full detail the adaptations we made. We refer to the original article by Kerr et al. [14] for the full details of the model implementation. This is an agent-based model that simulates SARS-CoV-2 transmission

and interventions. Each individual in the population is modeled as an agent in a network, with 500,000 agents. The model has four possible contact layers: "home", "school", "work" or "community". For each country, the model uses locationspecific demographics and household sizes. The model had the ability to simulate infections, interventions (quarantine, physical distancing, masks) and vaccination. In addition, we modeled the use of antiviral treatment. We did 100 runs for each scenario. We report the median of these runs and the 10th and 90th percentiles for the lower and upper bounds.

We assumed that antiviral treatment would be deployed under transmission of a variant similar to delta, with an increased 
medRxiv preprint doi: https://doi.org/10.1101/2021.11.10.21266139; this version posted November 11, 2021. The copyright holder for this preprint (which was not certified by peer review) is the author/funder, who has granted medRxiv a license to display the preprint in perpetuity.

It is made available under a CC-BY-NC-ND 4.0 International license .

transmissibility of $97 \%$ with respect to the ancestral variant [4]. We assumed that children are less likely to develop symptoms than adults but equally likely to become infected [29, 30], Table S2. Further, asymptomatic individuals are assumed to be $30 \%$ less infectious than symptomatic individuals [31]. These assumptions resulted in basic reproduction number $R_{0}$ for a Delta-like variant of approximately 4.95-5.68. Furthermore, we assumed that $40 \%$ of the population in each location was previously infected and is immune for the duration of the study (20 and 60\% were also explored in Sensitivity analysis). The population assumed to be previously infected was selected at random, so it is expected that some of the vaccinated individuals were already recovered.

\section{Disease dynamics}

Individuals in the network can be susceptible, exposed (infected but not infectious), asymptomatic, presymptomatic or symptomatic. Symptomatic individuals have one of three fates: they develop a mild, severe, or critical disease. All mild infected individuals recover, and infected individuals reaching a critical state can recover or die. The latent period is sampled from a log-normal distributions with a mean of 4.6 days. The length of time between becoming infectious and developing symptoms is sampled from a log-normal distribution with mean 1.1 days. The times to develop severe symptoms, to progress to become critically ill and to death are sampled from lognormal distributions with means 6.6, 1.5 and 10.7 days respectively. Asymptomatic and mild cases recover on average on 8 days (sampled from log-normal distributions), while severe and critically ill cases recover on average on 18.1 days. Infectiousness was assumed to be linearly correlated to viral load [32]. As with the original model [14], we modeled viral load having two modes: first, a high mode where viral load is highest, around or before symptom onset, and a low mode having a longer duration but a lower viral load (50\% lower than during the high mode).

\section{Vaccination}

We considered a leaky vaccine (that is, a vaccine that confers partial protection to all vaccinated individuals) [33] having three effects on vaccinated individuals: to reduce the probability of acquiring a SARS-CoV-2 infection (denoted byVESUS), to reduce the probability of developing COVID-19 symptoms after infection (denoted by $\mathrm{VE}_{\mathrm{SYMP}}$ ), and to reduce the probability of hospitalization conditioned on symptomatic infection (denoted by $\mathrm{VE}_{\mathrm{H}}$ ). Then it follows that

$$
\begin{gathered}
\mathrm{VE}_{\mathrm{DIS}}=1-\left(1-\mathrm{VE}_{\mathrm{SUS}}\right)\left(1-\mathrm{VE}_{\mathrm{SYMP}}\right) \\
\mathrm{VE}_{\mathrm{HOSP}}=1-\left(1-\mathrm{VE}_{\mathrm{DIS}}\right)\left(1-\mathrm{VE}_{\mathrm{H}}\right)
\end{gathered}
$$

where $\mathrm{VE}_{\mathrm{DIS}}$ and $\mathrm{VE}_{\mathrm{HOSP}}$ are the unconditional vaccine effectiveness on symptomatic infection and hospitalization respectively. Importantly, under this model vaccination does not influence onward transmission of infection except through a 
medRxiv preprint doi: https://doi.org/10.1101/2021.11.10.21266139; this version posted November 11, 2021. The copyright holder for this preprint (which was not certified by peer review) is the author/funder, who has granted medRxiv a license to display the preprint in perpetuity. It is made available under a CC-BY-NC-ND 4.0 International license .

reduction in SARS-CoV-2 infection. We used real world vaccine effectiveness estimates given in [34]. Table S1 summarizes all the parameters used in the model.

\section{Acknowledgements}

Funding: Scientific Computing Infrastructure at Fred Hutch was funded by ORIP grant S10OD028685. HJ was supported by R56AI143418 and R01CA152089 from the National Institutes of Health. LM, DD and HJ were supported by UM1 AI068635 from the National Institutes of Health. ERB was supported by the Infectious Diseases Clinical Research Consortium through the National Institute of Allergy and Infectious Diseases, part of the National Institutes of Health, under award number UM1AI148684. The content is solely the responsibility of the authors and does not necessarily represent the official views of the National Institutes of Health Author contributions: LM, ERB and HJ conceived the study. LM conducted the analysis and wrote the first draft of the manuscript. HJ, DD, and ERB contributed to writing the manuscript. Competing interests: The authors declare no competing interests. Code availability: Code will be available at: https:/github.com/lulelita

\section{Figures}

\section{References}

[1] Johns Hopkins Coronavirus Resource Center. Home - Johns Hopkins Coronavirus Resource Center. https: / / coronavirus.jhu. edu/, 2021. last accessed September 28th, 2021.

[2] Edouard Mathieu, Hannah Ritchie, Esteban Ortiz-Ospina, Max Roser, Joe Hasell, Cameron Appel, Charlie Giattino, and Lucas Rodés-Guirao. A global database of covid-19 vaccinations. Nature Human Behaviour, 5(7):947-953, 2021. doi: 10.1038/s41562-021-01122-8. URL https : / / doi .org/10.1038/s41562-021-01122-8.

[3] Jeffrey V. Lazarus, Scott C. Ratzan, Adam Palayew, Lawrence O. Gostin, Heidi J. Larson, Kenneth Rabin, Spencer Kimball, and Ayman El-Mohandes. A global survey of potential acceptance of a covid-19 vaccine. Nature Medicine, 27(2): 225-228, 2021. doi: 10.1038/s41591-020-1124-9. URL https : / / doi . org/10.1038/s41591-020-1124-9.

[4] Finlay Campbell, Brett Archer, Henry Laurenson-Schafer, Yuka Jinnai, Franck Konings, Neale Batra, Boris Pavlin, Katelijn Vandemaele, Maria D Van Kerkhove, Thibaut Jombart, Oliver Morgan, and Olivier le Polain de Waroux. Increased transmissibility and global spread of sars-cov-2 variants of concern as at june $2021 . \quad E u$ rosurveillance, 26(24):2100509, 2021. doi: https://doi.org/10.2807/1560-7917.ES.2021.26.24.2100509. URL https://www.eurosurveillance.org/content/10.2807/1560-7917.ES.2021.26.24.2100509. 
medRxiv preprint doi: https://doi.org/10.1101/2021.11.10.21266139; this version posted November 11, 2021. The copyright holder for this preprint (which was not certified by peer review) is the author/funder, who has granted medRxiv a license to display the preprint in perpetuity.

It is made available under a CC-BY-NC-ND 4.0 International license .
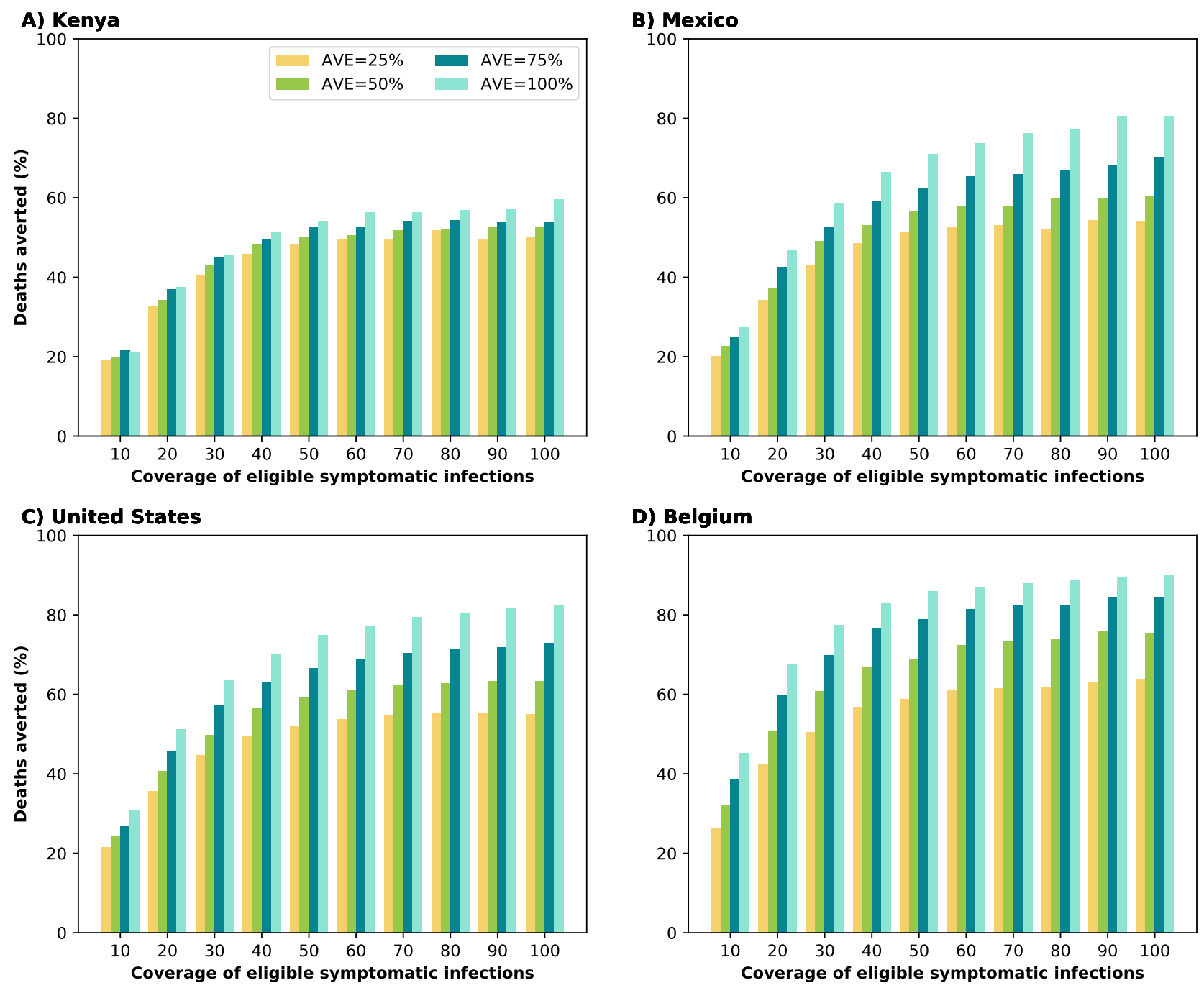

D) Belgium

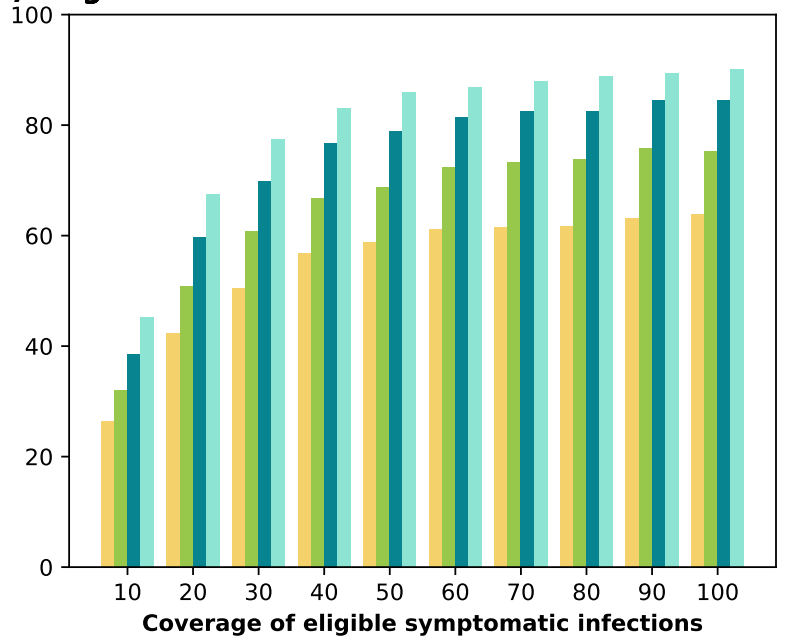

Figure 1: Percentage of deaths averted (compared to a baseline of no antiviral treatment) for A) Kenya, B) Mexico, C) United States and D) Belgium. For each country, we considered four possible values of AVE (25, 50, 75 or $100 \%$ reduction in viral load) and covering 10-100\% of eligible symptomatic individuals within the first 5 days of symptoms. 
medRxiv preprint doi: https://doi.org/10.1101/2021.11.10.21266139; this version posted November 11, 2021. The copyright holder for this preprint (which was not certified by peer review) is the author/funder, who has granted medRxiv a license to display the preprint in perpetuity.

It is made available under a CC-BY-NC-ND 4.0 International license .
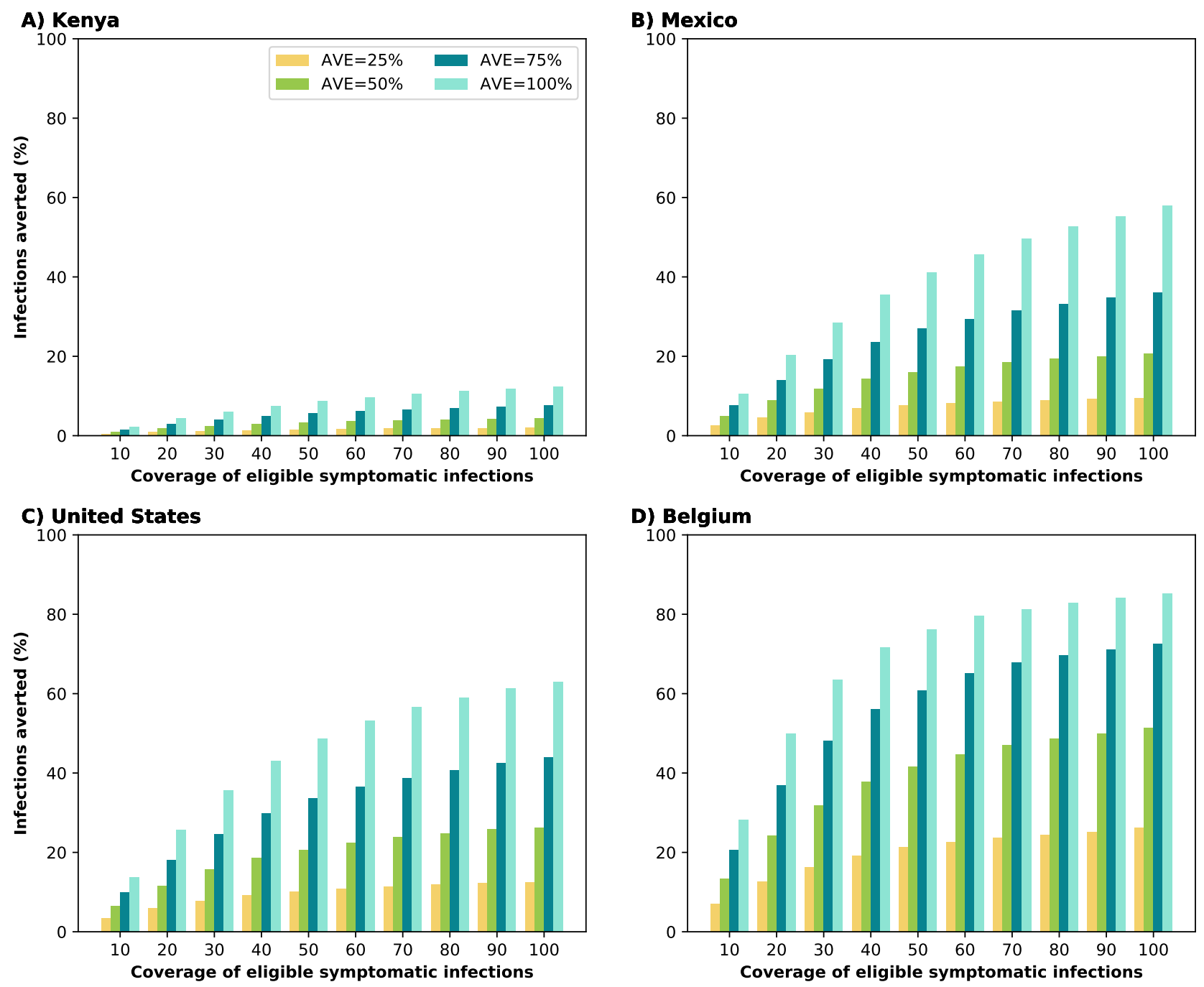

Figure 2: Percentage of infections averted (compared to a baseline of no antiviral treatment) for A) Kenya, B) Mexico, C) United States and D) Belgium. For each country, we considered four possible values of AVE (25, 50, 75 or $100 \%$ reduction in viral load) and covering 10-100\% of eligible symptomatic individuals within the first 5 days of symptoms 
medRxiv preprint doi: https://doi.org/10.1101/2021.11.10.21266139; this version posted November 11, 2021. The copyright holder for this preprint (which was not certified by peer review) is the author/funder, who has granted medRxiv a license to display the preprint in perpetuity.

It is made available under a CC-BY-NC-ND 4.0 International license .
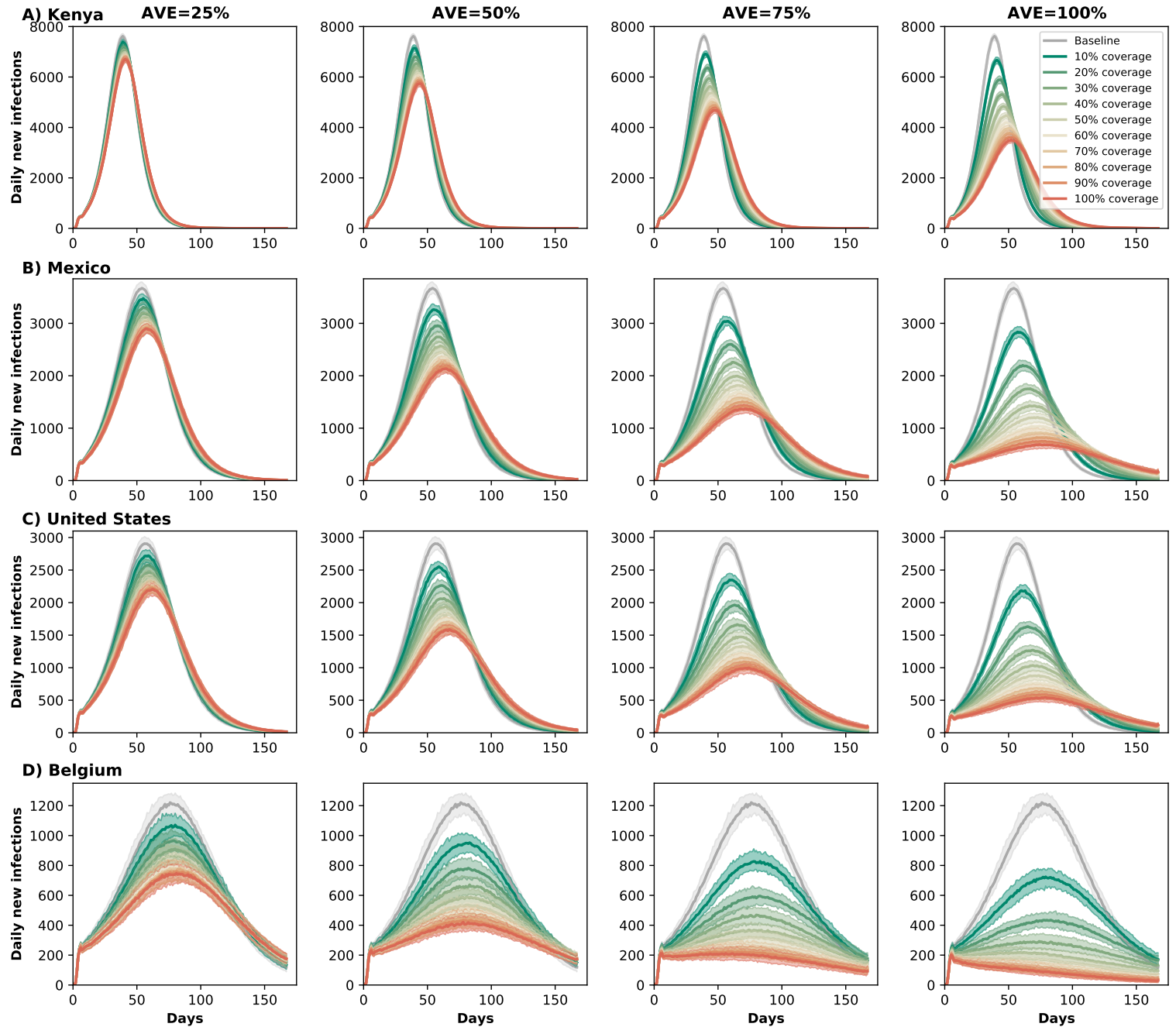

Figure 3: Daily new infections assuming no antiviral treatment (Baseline) or assuming coverage of 10-100\% of eligible symptomatic individuals in A) Kenya, B) Mexico, C) United States and D) Belgium. For each country, each column represents a different value of $\operatorname{AVE}(25,50,75$ or $100 \%$ reduction in viral load). 
medRxiv preprint doi: https://doi.org/10.1101/2021.11.10.21266139; this version posted November 11, 2021. The copyright holder for this preprint (which was not certified by peer review) is the author/funder, who has granted medRxiv a license to display the preprint in perpetuity.

It is made available under a CC-BY-NC-ND 4.0 International license .

Treatment started between days 0-2

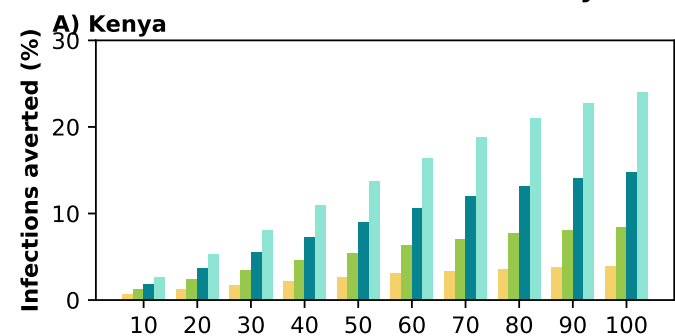

B) Mexico

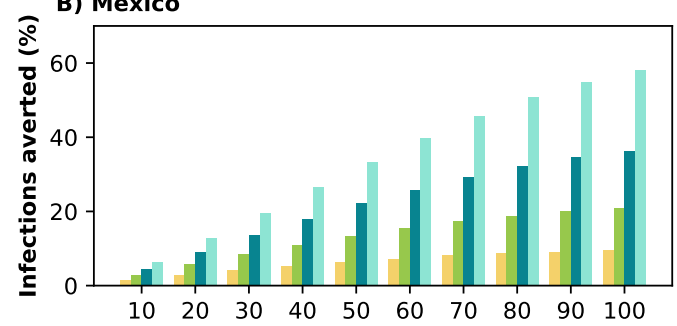

C) United States
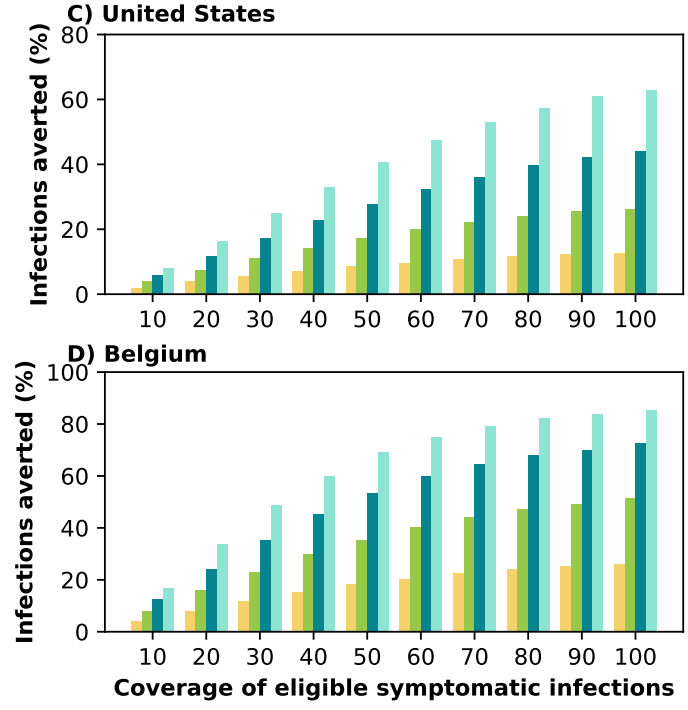

Treatment started between days 3-5
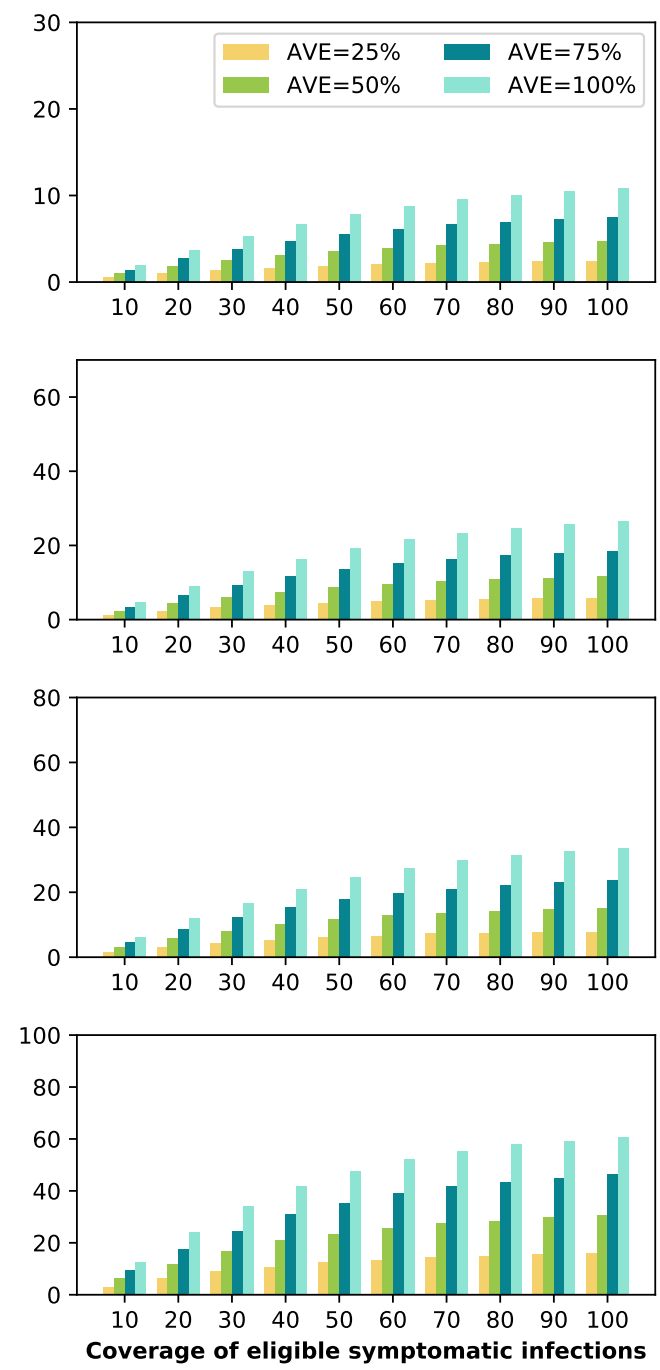

Figure 4: Percentage of deaths averted (compared to a baseline of no antiviral treatment) for A) Kenya, B) Mexico, C) United States and D) Belgium for early (within the first two days of symptoms, left column) or late (between days 2 and 5 of symptoms, right column) treatment. For each country, we considered four possible values of AVE $(25,50,75$ or $100 \%$ reduction in viral load) and covering $10-100 \%$ of eligible symptomatic individuals. 
medRxiv preprint doi: https://doi.org/10.1101/2021.11.10.21266139; this version posted November $11,2021$. The copyright holder for this preprint (which was not certified by peer review) is the author/funder, who has granted medRxiv a license to display the preprint in perpetuity. It is made available under a CC-BY-NC-ND 4.0 International license .

[5] James Hadfield, Colin Megill, Sidney M Bell, John Huddleston, Barney Potter, Charlton Callender, Pavel Sagulenko, Trevor Bedford, and Richard A Neher. Nextstrain: real-time tracking of pathogen evolution. Bioinformatics, 34(23):4121-4123, 05 2018. ISSN 1367-4803. doi: 10.1093/bioinformatics/bty407. URL https://doi.org/10.1093/bioinformatics/bty407.

[6] William Fischer, Joseph J Eron, Wayne Holman, Myron S Cohen, Lei Fang, Laura J Szewczyk, Timothy P Sheahan, Ralph Baric, Katie R Mollan, Cameron R Wolfe, Elizabeth R Duke, Masoud M Azizad, Katyna Borroto-Esoda, David A Wohl, Amy James Loftis, Paul Alabanza, Felicia Lipansky, and Wendy P Painter. Molnupiravir, an Oral Antiviral Treatment for COVID-19., Jun 2021.

[7] Merck. Merck and Ridgeback's Investigational Oral Antiviral Molnupiravir Reduced the Risk of Hospitalization or Death by Approximately 50 Percent Compared to Placebo for Patients with Mild or Moderate COVID-19 in Positive Interim Analysis of Phase 3 Study - Merc. https://www.merck.com/news/merck-and-ridgebacks-investigational-oral-antiviral-molnupirav October 2021. last accessed October 19th, 2021.

[8] CNN. Merck seeks FDA emergency use authorization for experimental antiviral Covid-19 treatment molnupiravir CNN, 2021. URL https://www. cnn.com/2021/10/11/health/molnupiravir-covid-19-antiviral-merck-r last accessed October 19th, 2021.

[9] Pfizer. Pfizer's Novel COVID-19 Oral Antiviral Treatment Candidate Reduced Risk of Hospitalization or Death by 89EPIC-HR Study IPfizer. https://www.pfizer.com/news/press-release/press-release-detail/pfizersNov 2021. last accessed Nov 5th, 2021.

[10] Gilead. Veklury® (Remdesivir) Significantly Reduced Risk of Hospitalization in High-Risk Patients with COVID-19. https://www.gilead.com/news-and-press/press-room/press-releases/2021/9/veklury-remdesivir September 2021. last accessed October 19th, 2021.

[11] Nature. How antiviral pill molnupiravir shot ahead in the COVID drug hunt. https://www.nature.com/articles/d41586-021-02783-1, October 2021. last accessed October 19 th, 2021.

[12] Centers for Disease Control and Prevention. Influenza Antiviral Medications: Summary for Clinicians I CDC. 
medRxiv preprint doi: https://doi.org/10.1101/2021.11.10.21266139; this version posted November $11,2021$. The copyright holder for this preprint (which was not certified by peer review) is the author/funder, who has granted medRxiv a license to display the preprint in perpetuity. It is made available under a CC-BY-NC-ND 4.0 International license .

https://www.cdc.gov/flu/professionals/antivirals/summary-clinicians.htm, . last accessed October 12th, 2021.

[13] Centers for Disease Control and Prevention. How to Optimize HIV Treatment I Treatment, Care, and Prevention for People with HIV I Clinicians I HIV I CDC. https://wWw.cdc.gov/hiv/clinicians/treatment/partner-prevention.html, . last accessed October 12th, 2021.

[14] Cliff C. Kerr, Robyn M. Stuart, Dina Mistry, Romesh G. Abeysuriya, Katherine Rosenfeld, Gregory R. Hart, Rafael C. Núñez, Jamie A. Cohen, Prashanth Selvaraj, Brittany Hagedorn, Lauren George, Michał Jastrzębski, Amanda S. Izzo, Greer Fowler, Anna Palmer, Dominic Delport, Nick Scott, Sherrie L. Kelly, Caroline S. Bennette, Bradley G. Wagner, Stewart T. Chang, Assaf P. Oron, Edward A. Wenger, Jasmina Panovska-Griffiths, Michael Famulare, and Daniel J. Klein. Covasim: An agent-based model of covid-19 dynamics and interventions. $\quad$ PLOS Computational Biology, 17(7):1-32, 07 2021. doi: 10.1371/journal.pcbi.1009149. URL https://doi.org/10.1371/journal.pcbi.1009149.

[15] Secretaria de Salud, Mexico. Vacuna COVID. http://vacunacovid.gob.mx/wordpress/, 2021. last accessed October 12th, 2021.

[16] Centers for Disease Control and Prevention. COVID-19 Vaccination and Case Trends by Age Group, United States Vaccinations, 2021. URL https://data.cdc.gov/Vaccinations/COVID-19-Vaccination-and-Case-Trends-by-Age-Group-/gxj9 last accessed October 12th, 2021.

[17] Sciensano. Belgium COVID-19 Dashboard - Sciensano > Vaccination, $2021 . \quad$ URL https: //datastudio.google.com/u/0/reporting/c14a5cfc-cab7-4812-848c-0369173148ab/page/hoM last accessed October 12th, 2021.

[18] GAVI. Kenya completes its first round of COVID-19 vaccinations I Gavi, the Vaccine Alliance. https://www.gavi.org/vaccineswork/kenya-completes-its-first-round-covid-19-vaccinations, 2021. last accessed October 12th, 2021.

[19] COVIDESTIM. covidestim: COVID-19 nowcasting. https://covidestim.org/, 2020. URL https://covidestim.org/. last accessed October 12th, 2021. 
medRxiv preprint doi: https://doi.org/10.1101/2021.11.10.21266139; this version posted November 11, 2021. The copyright holder for this preprint (which was not certified by peer review) is the author/funder, who has granted medRxiv a license to display the preprint in perpetuity. It is made available under a CC-BY-NC-ND 4.0 International license .

[20] Washington State Department of Health. COVID-19 Data Dashboard, 2021. https://www.doh.wa.gov/Emergencies/COVID19/DataDashboard\#dashboard. last accessed October 12th, 2021.

[21] Diana Buitrago-Garcia, Dianne Egli-Gany, Michel J. Counotte, Stefanie Hossmann, Hira Imeri, Aziz Mert Ipekci, Georgia Salanti, and Nicola Low. Occurrence and transmission potential of asymptomatic and presymptomatic sarscov-2 infections: A living systematic review and meta-analysis. PLOS Medicine, 17(9):e1003346-, 09 2020. URL https://doi.org/10.1371/journal.pmed.1003346.

[22] Medicines Patent Pool, UN. MPP and MSD announce new licence for investigational COVID-19 treatment. https://medicinespatentpool.org/news-publications-post/mpp-msd-new-licence-announcement-m October 2021. URL https: / / medicinespatentpool org/news-publications-post/mpp-msd-new-licence-a last accessed October 27th, 2021.

[23] Youngji Jo, Lise Jamieson, Ijeoma Edoka, Lawrence Long, Sheetal Silal, Juliet R.C. Pulliam, Harry Moultrie, Ian Sanne, Gesine Meyer-Rath, and Brooke E Nichols. Cost-effectiveness of remdesivir and dexamethasone for covid-19 treatment in south africa. medRxiv, 2020. doi: 10.1101/2020.09.24.20200196. URL https://wWw.medrxiv.org/content/early/2020/09/27/2020.09.24.20200196.

[24] Ashish Goyal, E. Fabian Cardozo-Ojeda, and Joshua T. Schiffer. Potency and timing of antiviral therapy as determinants of duration of sars-cov-2 shedding and intensity of inflammatory response. Science Advances, 6(47):eabc7112, 2021/11/08 2020. doi: 10.1126/sciadv.abc7112. URL https://doi . org/10.1126/sciadv.abc7112.

[25] Kathy Leung, Mark Jit, Gabriel M Leung, and Joseph $\mathrm{T}$ Wu. Comparative effectiveness of allocation strategies of covid-19 vaccines and antivirals against emerging sars-cov-2 variants of concern in east asia and pacific region. medRxiv, 2021. doi: 10.1101/2021.10.20.21265245. URL https://wWw.medrxiv.org/content/early/2021/10/20/2021.10.20.21265245.

[26] Andrea Torneri, Pieter Libin, Joris Vanderlocht, Anne-Mieke Vandamme, Johan Neyts, and Niel Hens. A prospect on the use of antiviral drugs to control local outbreaks of covid-19. medRxiv, 2020. doi: 10.1101/2020.03.19.20038182. URL https://www.medrxiv.org/content/early/2020/03/30/2020.03.19.20038182.

[27] Charles Whittaker, Oliver J. Watson, Carlos Alvarez-Moreno, Nasikarn Angkasekwinai, Adhiratha Boonyasiri, Luis Carlos Triana, Duncan Chanda, Lantharita Charoenpong, Methee Chayakulkeeree, Graham S. Cooke, Julio 
medRxiv preprint doi: https://doi.org/10.1101/2021.11.10.21266139; this version posted November 11, 2021. The copyright holder for this preprint (which was not certified by peer review) is the author/funder, who has granted medRxiv a license to display the preprint in perpetuity. It is made available under a CC-BY-NC-ND 4.0 International license .

Croda, Zulma M Cucunubá, Bimandra A. Djaafara, Cassia F. Estofolete, Maria Eugenia Grillet, Nuno R. Faria, Silvia Figueiredo Costa, David A. Forero-Peña, Diana M. Gibb, Anthony C Gordon, Raph L. Hamers, Arran Hamlet, Vera Irawany, Anupop Jitmuang, Nukool Keurueangkul, Teresia Njoki Kimani, Margarita Lampo, Anna S. Levin, Gustavo Lopardo, Rima Mustafa, Shevanthi Nayagam, Thundon Ngamprasertchai, Ng'ang'a Irene Hannah Njeri, Mauricio L. Nogueira, Esteban Ortiz-Prado, Mauricio W. Perroud, Andrew N. Phillips, Panuwat Promsin, Ambar Qavi, Alison J. Rodger, Ester C. Sabino, Sorawat Sangkaew, Djayanti Sari, Rujipas Sirijatuphat, Andrei C. Sposito, Pratthana Srisangthong, Hayley A. Thompson, Zarir Udwadia, Sandra Valderrama-Beltrán, Peter Winskill, Azra C. Ghani, Patrick G.T. Walker, and Timothy B. Hallett. Understanding the potential impact of different drug properties on sars-cov-2 transmission and disease burden: A modelling analysis. medRxiv, 2021. doi: 10.1101/2021.06.17.21259078. URL https://www.medrxiv.org/content/early/2021/06/20/2021.06.17.21259078.

[28] WHO. WHO, UN set out steps to meet world COVID vaccination targets. https://www.who.int/news/item/07-10-2021-who-un-set-out-steps-to-meet-world-covid-vaccina 2021. URL https: / /www.who.int/news/item/07-10-2021-who-un-set-out-steps-to-meet-world-covid-

[29] Q Bi, J Lessler, I Eckerle, S A Lauer, L Kaiser, N Vuilleumier, D A T Cummings, A Flahault, D Petrovic, I Guessous, S Stringhini, A S Azman, and SeroCoV-POP Study Group. Household transmission of SARS-CoV-2: Insights from a population-based serological survey. medRxiv, $2021 . \quad$ URL https://www.medrxiv.org/content/10.1101/2020.11.04.20225573v2.

[30] Christelle Meuris, Cécile Kremer, Anton Geerinck, Medea Locquet, Olivier Bruyère, Justine Defêche, Cécile Meex, Marie-Pierre Hayette, Loic Duchene, Patricia Dellot, Samira Azarzar, Nicole Maréchal, Anne-Sophie Sauvage, Frederic Frippiat, Jean-Baptiste Giot, Philippe Léonard, Karine Fombellida, Michel Moutschen, Keith Durkin, Maria Artesi, Vincent Bours, Christel Faes, Niel Hens, and Gilles Darcis. Transmission of SARS-CoV-2 After COVID-19 Screening and Mitigation Measures for Primary School Children Attending School in Liège, Belgium. JAMA Network Open, 4(10):e2128757-e2128757, 10 2021. ISSN 2574-3805. doi: 10.1001/jamanetworkopen.2021.28757. URL https://doi.org/10.1001/jamanetworkopen.2021.28757.

[31] CDC. COVID-19 Pandemic Planning Scenarios. URL https: / /www. cdc.gov/coronavirus/2019-ncov/hcp/plannin

[32] Hannah W Despres, Margaret G Mills, David J Shirley, Madaline M Schmidt, Meei-Li Huang, Keith R Jerome, Alexander L Greninger, and Emily A Bruce. Quantitative measurement of infectious virus in sars-cov-2 alpha, delta and ep- 
medRxiv preprint doi: https://doi.org/10.1101/2021.11.10.21266139; this version posted November 11, 2021. The copyright holder for this preprint (which was not certified by peer review) is the author/funder, who has granted medRxiv a license to display the preprint in perpetuity. It is made available under a CC-BY-NC-ND 4.0 International license .

silon variants reveals higher infectivity (viral titer:rna ratio) in clinical samples containing the delta and epsilon variants. medRxiv, Sep 2021. doi: 10.1101/2021.09.07.21263229.

[33] M Elizabeth Halloran, Claudio J Struchiner, and Ira M Longini. Study designs for evaluating different efficacy and effectiveness aspects of vaccines. American Journal of Epidemiology, 146(10):789-803, 1997. ISSN 0002-9262 (Print).

[34] Centers for Disease Control and Prevention. CDC COVID Data Tracker. https://covid.cdc.gov/covid-data-tracker/\#vaccine-effectiveness, 2020. last accessed October 19th, 2021.

[35] Stephen A Lauer, Kyra H Grantz, Qifang Bi, Forrest K Jones, Qulu Zheng, Hannah R Meredith, Andrew S Azman, Nicholas G Reich, and Justin Lessler. The incubation period of coronavirus disease 2019 (COVID-19) from publicly reported confirmed cases: Estimation and application. Annals of Internal Medicine, 2020. ISSN 1539-3704. doi: 10.7326/M20-0504. URL http://www.ncbi.nlm.nih.gov/pubmed/32150748.

[36] Roman Wölfel, Victor M. Corman, Wolfgang Guggemos, Michael Seilmaier, Sabine Zange, Marcel A. Müller, Daniela Niemeyer, Terry C. Jones, Patrick Vollmar, Camilla Rothe, Michael Hoelscher, Tobias Bleicker, Sebastian Brünink, Julia Schneider, Rosina Ehmann, Katrin Zwirglmaier, Christian Drosten, and Clemens Wendtner. Virological assessment of hospitalized patients with covid-2019. Nature, 581(7809):465-469, 2020. doi: 10.1038/s41586-020-2196-X. URL https://doi.org/10.1038/s41586-020-2196-x.

[37] Natalie M Linton, Tetsuro Kobayashi, Yichi Yang, Katsuma Hayashi, Andrei R Akhmetzhanov, Sung-Mok Jung, Baoyin Yuan, Ryo Kinoshita, and Hiroshi Nishiura. Incubation period and other epidemiological characteristics of 2019 novel coronavirus infections with right truncation: A statistical analysis of publicly available case data. Journal of clinical medicine, 9(2):538, 02 2020. doi: 10.3390/jcm9020538. URL https://pubmed.ncbi.nlm.nih.gov/32079150.

[38] Dawei Wang, Bo Hu, Chang Hu, Fangfang Zhu, Xing Liu, Jing Zhang, Binbin Wang, Hui Xiang, Zhenshun Cheng, Yong Xiong, Yan Zhao, Yirong Li, Xinghuan Wang, and Zhiyong Peng. Clinical Characteristics of 138 Hospitalized Patients With 2019 Novel Coronavirus-Infected Pneumonia in Wuhan, China. JAMA, 323(11):1061-1069, 03 2020. ISSN 0098-7484. doi: 10.1001/jama.2020.1585. URL https : / / doi . org/10.1001/jama.2020.1585.

[39] Jun Chen, Tangkai Qi, Li Liu, Yun Ling, Zhiping Qian, Tao Li, Feng Li, Qingnian Xu, Yuyi Zhang, Shuibao Xu, Zhigang Song, Yigang Zeng, Yinzhong Shen, Yuxin Shi, Tongyu Zhu, and 
medRxiv preprint doi: https://doi.org/10.1101/2021.11.10.21266139; this version posted November 11, 2021. The copyright holder for this preprint (which was not certified by peer review) is the author/funder, who has granted medRxiv a license to display the preprint in perpetuity. It is made available under a CC-BY-NC-ND 4.0 International license .

Hongzhou Lu. Clinical progression of patients with covid-19 in shanghai, china. Journal of Infection, 80(5):e1-e6, 2020. ISSN 0163-4453. doi: https://doi.org/10.1016/j.jinf.2020.03.004. URL https://www.sciencedirect.com/science/article/pii/s0163445320301195.

[40] Robert Verity, Lucy C Okell, Ilaria Dorigatti, Peter Winskill, Charles Whittaker, Natsuko Imai, Gina CuomoDannenburg, Hayley Thompson, Patrick G T Walker, Han Fu, Amy Dighe, Jamie T Griffin, Marc Baguelin, Sangeeta Bhatia, Adhiratha Boonyasiri, Anne Cori, Zulma Cucunubá, Rich FitzJohn, Katy Gaythorpe, Will Green, Arran Hamlet, Wes Hinsley, Daniel Laydon, Gemma Nedjati-Gilani, Steven Riley, Sabine van Elsland, Erik Volz, Haowei Wang, Yuanrong Wang, Xiaoyue Xi, Christl A Donnelly, Azra C Ghani, and Neil M Ferguson. Estimates of the severity of coronavirus disease 2019: a model-based analysis. The Lancet Infectious Diseases, 20(6):669-677, 2021/11/01 2020. doi: 10.1016/S1473-3099(20)30243-7. URL https : / / doi . org/10.1016/s1473-3099(20) 30243-7.

[41] Megan O’Driscoll, Gabriel Ribeiro Dos Santos, Lin Wang, Derek A. T. Cummings, Andrew S. Azman, Juliette Paireau, Arnaud Fontanet, Simon Cauchemez, and Henrik Salje. Age-specific mortality and immunity patterns of sars-cov-2. Nature, 590(7844):140-145, 2021. doi: 10.1038/s41586-020-2918-0. URL https://doi.org/10.1038/s41586-020-2918-0.

[42] Nick F Brazeau, Robert Verity, Sara Jenks, Han Fu, Charles Whittaker, Pete Winskill, Ilaria Dorigatti, Patrick G T Walker, Steven Riley, Ricardo P Schnekenbert, Henrique Hoeltgebaum, Thomas A Mellan, Swapnil Mishra, H Juliette T Unwin, Oliver J Watson, Zulma Cucunuba, Marc Baguelin, Lilith K Whittles, Samir Bhatt, Azra C. Ghani, Ferguson Neil M., and Lucy C Okell. Report 34 - COVID-19 Infection Fatality Ratio Estimates from Seroprevalence. https://www.imperial.ac.uk/mrc-global-infectious-disease-analysis/covid-19/report-34-ifr/ 2020.

[43] Neil M Ferguson, Daniel Laydon, Gemma Nedjati-Gilani, Natsuko Imai, Kylie Ainslie, Marc Baguelin, Sangeeta Bhatia, Adhiratha Boonyasiri, Zulma Cucunubá, Gina Cuomo-Dannenburg, Amy Dighe, Ilaria Dorigatti, Han Fu, Katy Gaythorpe, Will Green, Arran Hamlet, Wes Hinsley, Lucy C Okell, Sabine van Elsland, Hayley Thompson, Robert Verity, Erik Volz, Haowei Wang, Yuanrong Wang, Patrick G T Walker, Caroline Walters, Peter Winskill, Charles Whittaker, Christl A Donnelly, Steven Riley, and Azra C Ghani. Impact of non-pharmaceutical interventions (NPIs) to reduce COVID-19 mortality and healthcare demand. 2020. URL https : / / doi . org/10.25561/77482.

[44] Russell M. Viner, Oliver T. Mytton, Chris Bonell, G. J. Melendez-Torres, Joseph Ward, Lee Hudson, Claire Waddington, 
medRxiv preprint doi: https://doi.org/10.1101/2021.11.10.21266139; this version posted November 11, 2021. The copyright holder for this preprint (which was not certified by peer review) is the author/funder, who has granted medRxiv a license to display the preprint in perpetuity. It is made available under a CC-BY-NC-ND 4.0 International license .

James Thomas, Simon Russell, Fiona Van Der Klis, Archana Koirala, Shamez Ladhani, Jasmina Panovska-Griffiths, Nicholas G. Davies, Robert Booy, and Rosalind M. Eggo. Susceptibility to SARS-CoV-2 infection among children and adolescents compared with adults: A systematic review and meta-analysis. JAMA Pediatrics, 175(2):143-156, 2021. ISSN 21686211. doi: 10.1001/jamapediatrics.2020.4573.

[45] Yong-Hoon Lee, Chae Moon Hong, Dae Hyun Kim, Taek Hoo Lee, and Jaetae Lee. Clinical course of asymptomatic and mildly symptomatic patients with coronavirus disease admitted to community treatment centers, South Korea. Emerging Infectious Diseases, Oct, 2020. doi: 10.3201/eid2610.201620. URL https://wwwnc.cdc.gov/eid/article/26/10/20-1620_article.

[46] Kenji Mizumoto, Katsushi Kagaya, Alexander Zarebski, and Gerardo Chowell. Estimating the asymptomatic proportion of coronavirus disease 2019 (COVID-19) cases on board the Diamond Princess cruise ship, Yokohama, Japan, 2020. Euro Surveillance, 25(10), 2020. URL doi .org/10.2807/1560-7917. 
medRxiv preprint doi: https://doi.org/10.1101/2021.11.10.21266139; this version posted November 11, 2021. The copyright holder for this preprint (which was not certified by peer review) is the author/funder, who has granted medRxiv a license to display the preprint in perpetuity.

It is made available under a CC-BY-NC-ND 4.0 International license.

\section{Supplemental Information}

Table S1: Parameters used in the model.

\begin{tabular}{|c|c|c|}
\hline Parameter & Distribution (mean, SD) & Reference \\
\hline Latent period & lognormal $(4.5,1.5)$ & {$[14,35]$} \\
\hline Infectious period for asymptomatic and mild cases & lognormal $(8,2)$ & {$[14,36]$} \\
\hline Duration of presymptomatic period & lognormal $(1.1,0.9)$ & {$[14,37]$} \\
\hline $\begin{array}{l}\text { Length of time from symptom onset to hospital- } \\
\text { ization }\end{array}$ & lognormal $(6.6,4.9)$ & {$[14,37,38]$} \\
\hline Length of time from hospitalization to critically ill & lognormal $(1.5,1)$ & {$[14,38,39]$} \\
\hline Length of time from critically ill to death & $\operatorname{lognormal}(10.7,4.8)$ & {$[14,40]$} \\
\hline $\begin{array}{l}\text { Time from onset of symptoms to recovery for se- } \\
\text { vere and critically ill cases }\end{array}$ & lognormal $(18.1,6.3)$ & {$[14,40]$} \\
\hline Age-stratified mortality rates & varied by age & {$[14,41,42]$} \\
\hline $\begin{array}{l}\text { Age-stratified probability of developing symp- } \\
\text { toms }\end{array}$ & Table S2 & {$[14,40,43]$} \\
\hline Fraction of symptomatic infections $<15$ year old & 0.25 & [44] \\
\hline Fraction of symptomatic infections $\geq 15$ year old & 0.6 & {$[31,45,46]$} \\
\hline Vaccine efficacy against infection, $\mathrm{VE}_{\mathrm{SUS}}$ & 59.6 & [34] \\
\hline $\begin{array}{l}\text { Vaccine efficacy against symptomatic infection, } \\
V_{\text {DIS }}\end{array}$ & 67.5 & [34] \\
\hline Vaccine efficacy against Hospitalization, $\mathrm{VE}_{\mathrm{HOSP}}$ & 87.65 & [34] \\
\hline Antiviral effect, AVE & $25,50,75,100$ & assumed \\
\hline Antiviral effect on hospitalization, $\mathrm{AV}_{\mathrm{H}}$, & 50 or 80 & {$[7,10]$} \\
\hline
\end{tabular}

Table S2: Age-specific parameters for disease progression.

\begin{tabular}{lrrrrrrrrrrr}
\hline Parameter & $\mathbf{0 - 9}$ & $\mathbf{1 0 - 1 9}$ & $\mathbf{2 0 - 2 9}$ & $\mathbf{3 0 - 3 9}$ & $\mathbf{4 0 - 4 9}$ & $\mathbf{5 0 - 5 9}$ & $\mathbf{6 0 - 6 9}$ & $\mathbf{7 0 - 7 9}$ & $\mathbf{8 0 - 8 9}$ & $\mathbf{9 0 +}$ \\
\hline Probability of severe disease & 0.0005 & 0.00165 & 0.0072 & 0.0208 & 0.0343 & 0.0765 & 0.1328 & 0.20655 & 0.2457 & 0.2457 \\
\hline Probability of critical disease & 0.00003 & 0.00008 & 0.00036 & 0.00104 & 0.00216 & 0.00933 & 0.03639 & 0.08923 & 0.1742 & 0.1742 \\
\hline Probability of death & 0.00002 & 0.00002 & 0.0001 & 0.00032 & 0.00098 & 0.00265 & 0.00766 & 0.02439 & 0.08292 & 0.1619 \\
\hline
\end{tabular}


medRxiv preprint doi: https://doi.org/10.1101/2021.11.10.21266139; this version posted November 11, 2021. The copyright holder for this preprint (which was not certified by peer review) is the author/funder, who has granted medRxiv a license to display the preprint in perpetuity.

It is made available under a CC-BY-NC-ND 4.0 International license .
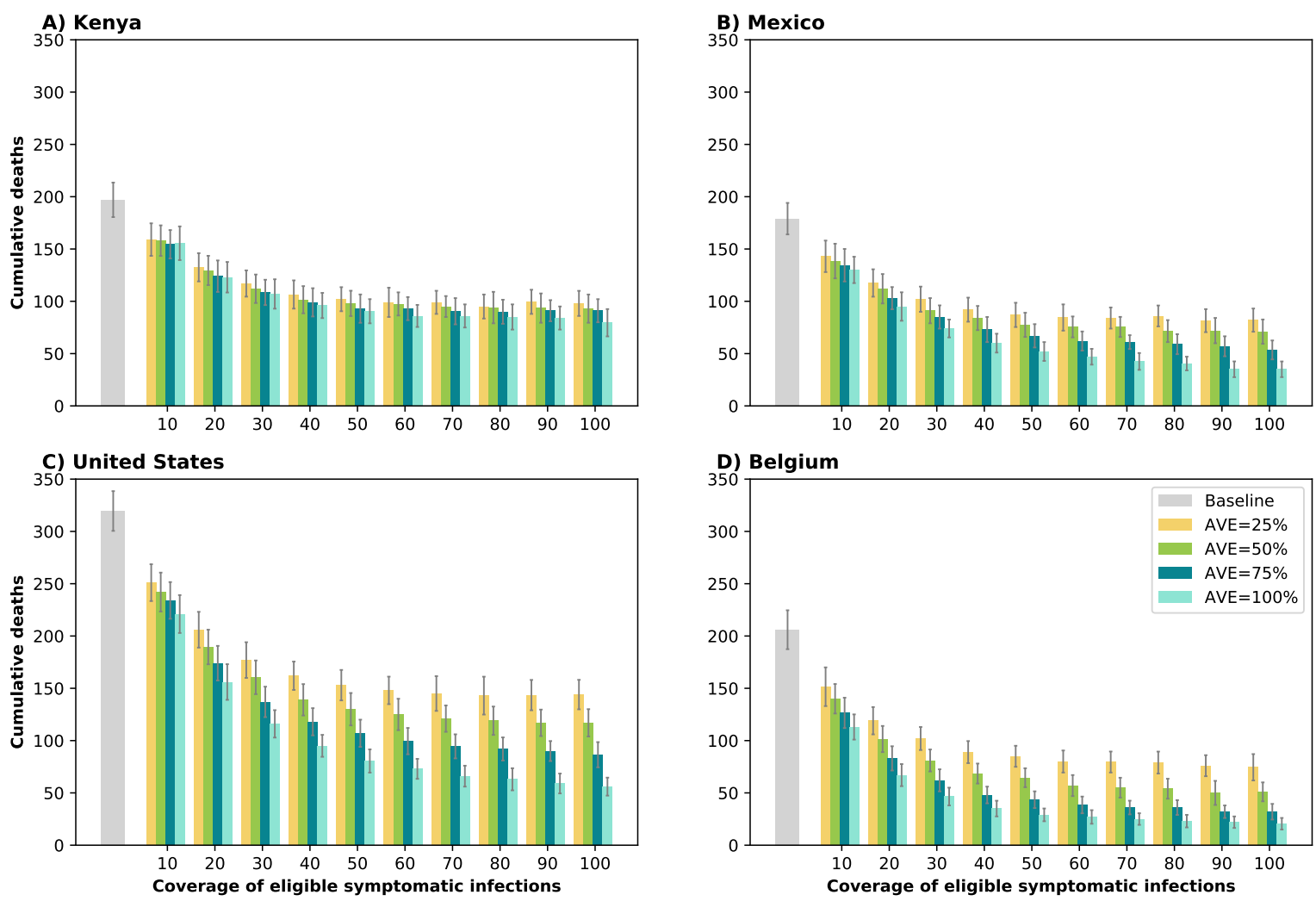

Figure S1: Cumulative deaths over next 6 months for A) Kenya, B) Mexico, C) United States and D) Belgium. For each country, we considered four possible values of $\operatorname{AVE}(25,50,75$ or $100 \%$ reduction in viral load) and covering $10-100 \%$ of eligible symptomatic individuals within the first 5 days of symptoms. Gray bars represent baseline cumulative deaths in absence of antiviral treatment. 
medRxiv preprint doi: https://doi.org/10.1101/2021.11.10.21266139; this version posted November 11, 2021. The copyright holder for this preprint (which was not certified by peer review) is the author/funder, who has granted medRxiv a license to display the preprint in perpetuity.

It is made available under a CC-BY-NC-ND 4.0 International license .
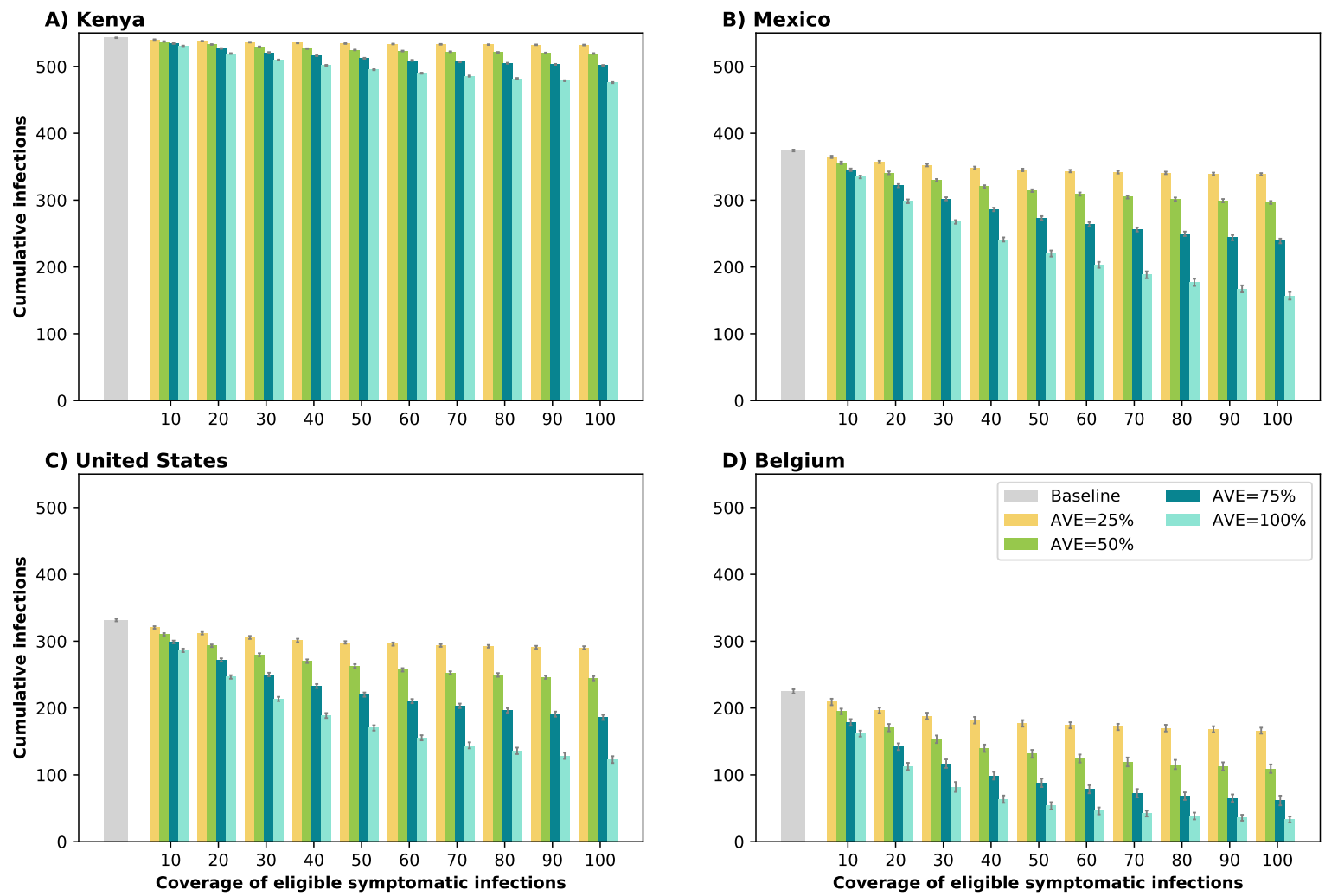

Figure S2: Cumulative infections over next 6 months for A) Kenya, B) Mexico, C) United States and D) Belgium. For each country, we considered four possible values of AVE $(25,50,75$ or $100 \%$ reduction in viral load) and covering $10-100 \%$ of eligible symptomatic individuals within the first 5 days of symptoms. Gray bars represent baseline cumulative infections in absence of antiviral treatment. 
medRxiv preprint doi: https://doi.org/10.1101/2021.11.10.21266139; this version posted November 11, 2021. The copyright holder for this preprint (which was not certified by peer review) is the author/funder, who has granted medRxiv a license to display the preprint in perpetuity.

It is made available under a CC-BY-NC-ND 4.0 International license .
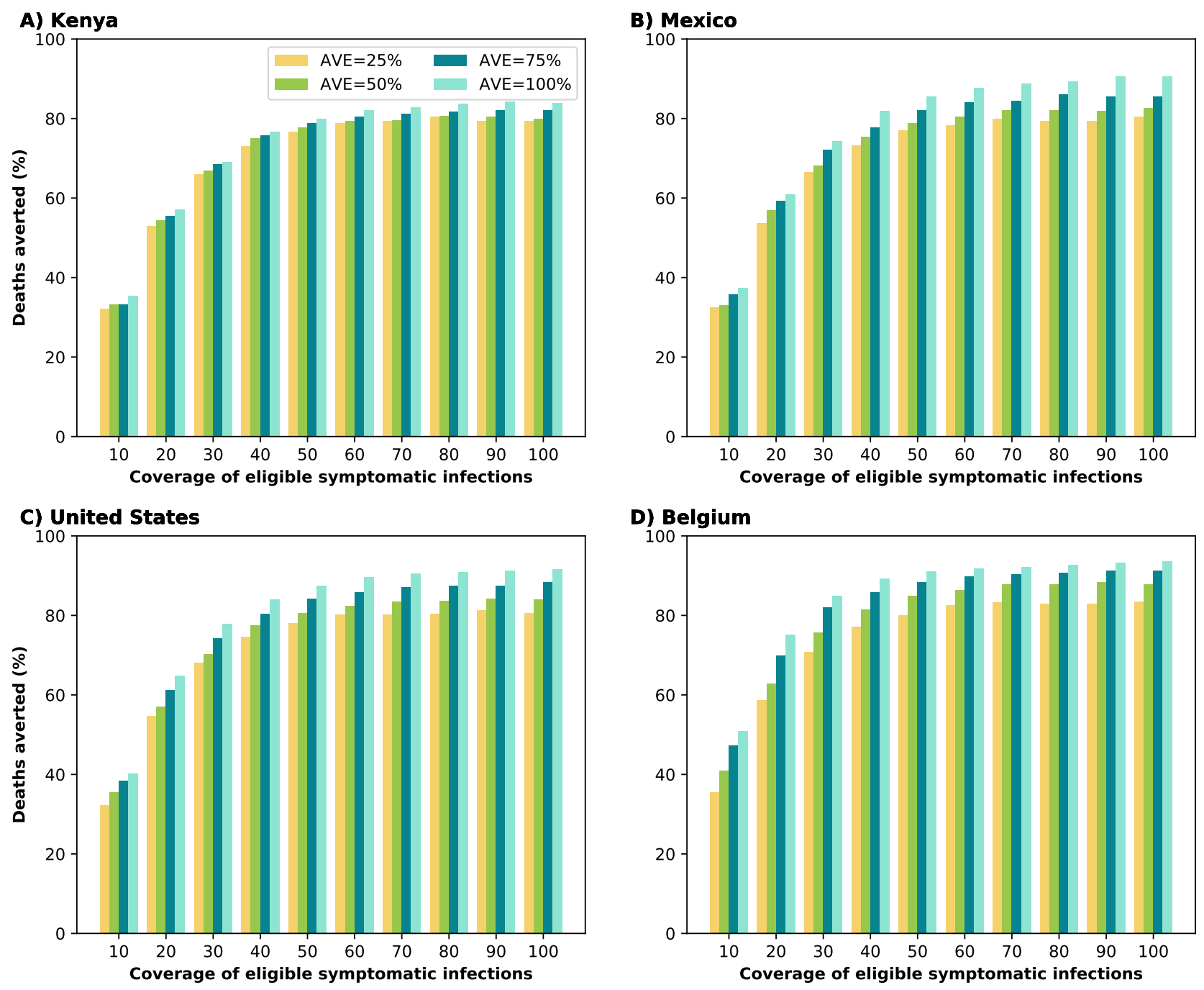

D) Belgium

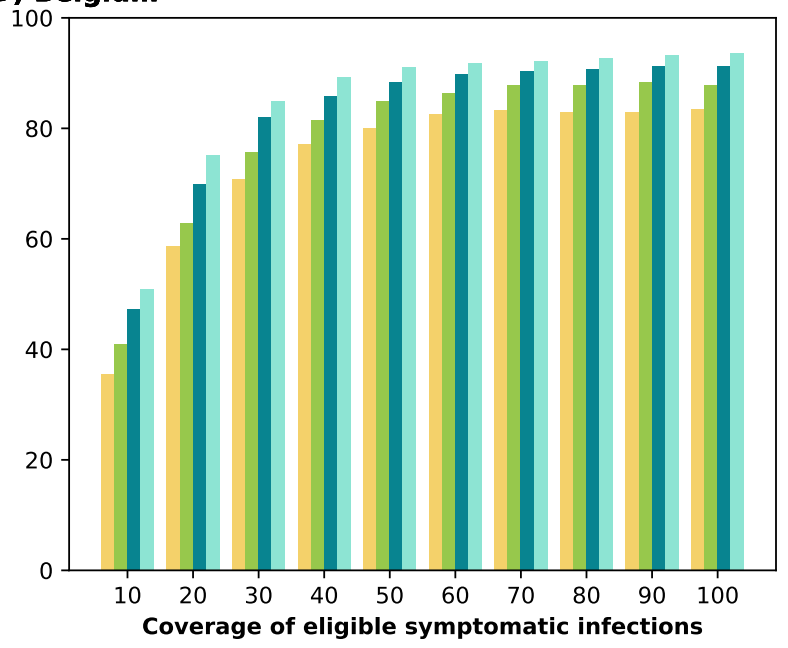

Figure S3: Percentage of deaths averted (compared to a baseline of no antiviral treatment) for A) Kenya, B) Mexico, C) United States and D) Belgium assuming antiviral treatment would reduce hospitalizations by $80 \%$. For each country, we considered four possible values of $\operatorname{AVE}(25,50,75$ or $100 \%$ reduction in viral load) and covering 10-100\% of eligible symptomatic individuals within the first 5 days of symptoms. 
medRxiv preprint doi: https://doi.org/10.1101/2021.11.10.21266139; this version posted November 11, 2021. The copyright holder for this preprint (which was not certified by peer review) is the author/funder, who has granted medRxiv a license to display the preprint in perpetuity.

It is made available under a CC-BY-NC-ND 4.0 International license .
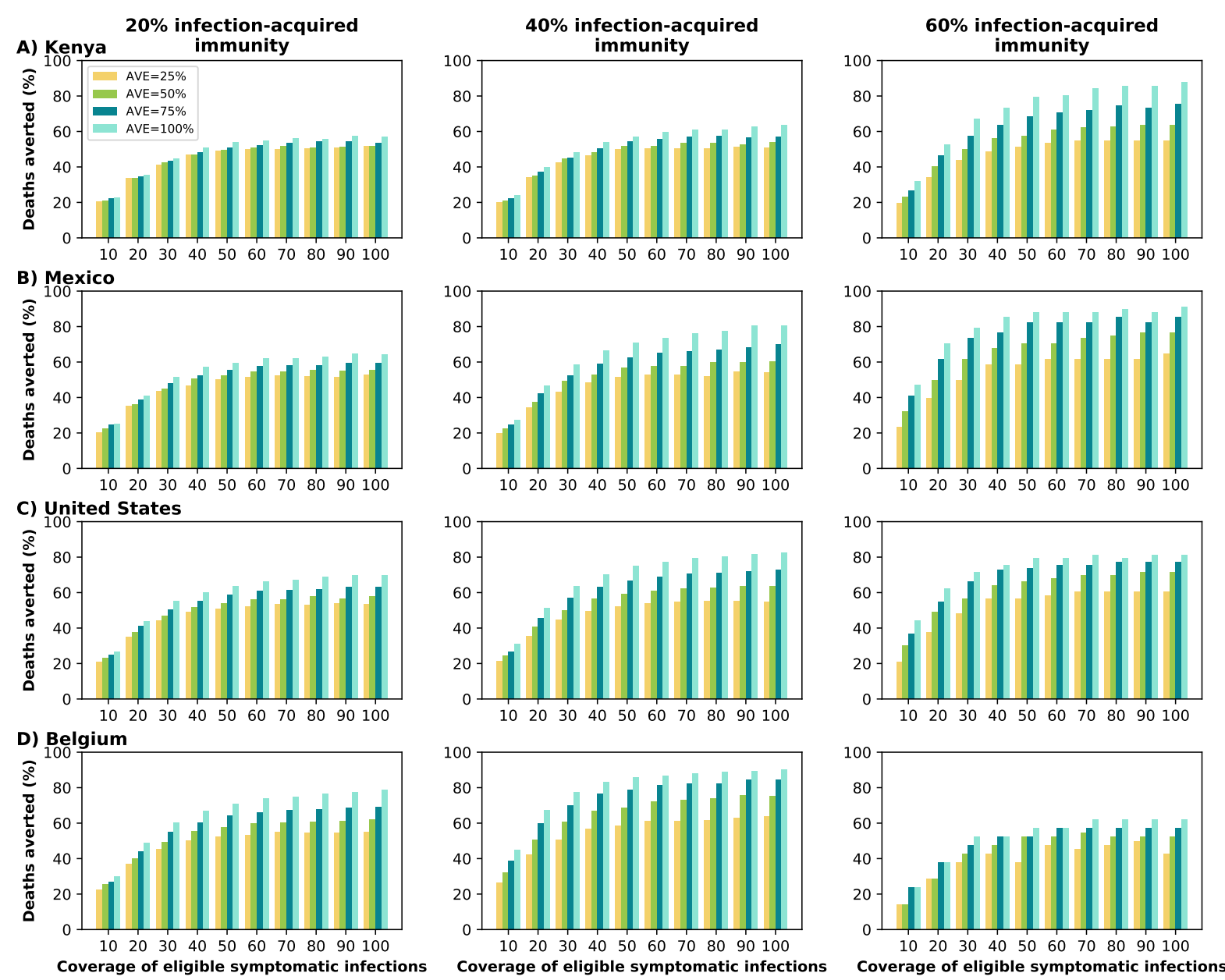

Figure S4: Proportion of deaths averted for A) Kenya, B) Mexico, C) United States and D) Belgium assuming 20 (left), 40 (middle) or $60 \%$ (right) of the population has been previously infected and is currently immune. For each country, we considered four possible values of $\operatorname{AVE}(25,50,75$ or $100 \%$ reduction in viral load) and covering $10-100 \%$ of eligible symptomatic individuals within the first 5 days of symptoms. Gray bars represent baseline cumulative deaths in absence of antiviral treatment. 
medRxiv preprint doi: https://doi.org/10.1101/2021.11.10.21266139; this version posted November 11, 2021. The copyright holder for this preprint (which was not certified by peer review) is the author/funder, who has granted medRxiv a license to display the preprint in perpetuity.

It is made available under a CC-BY-NC-ND 4.0 International license .
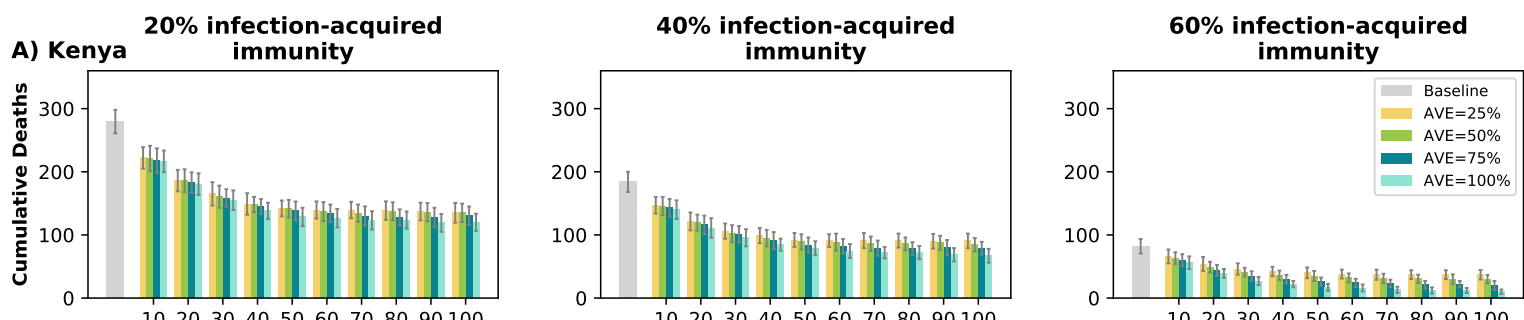

B) Mexico
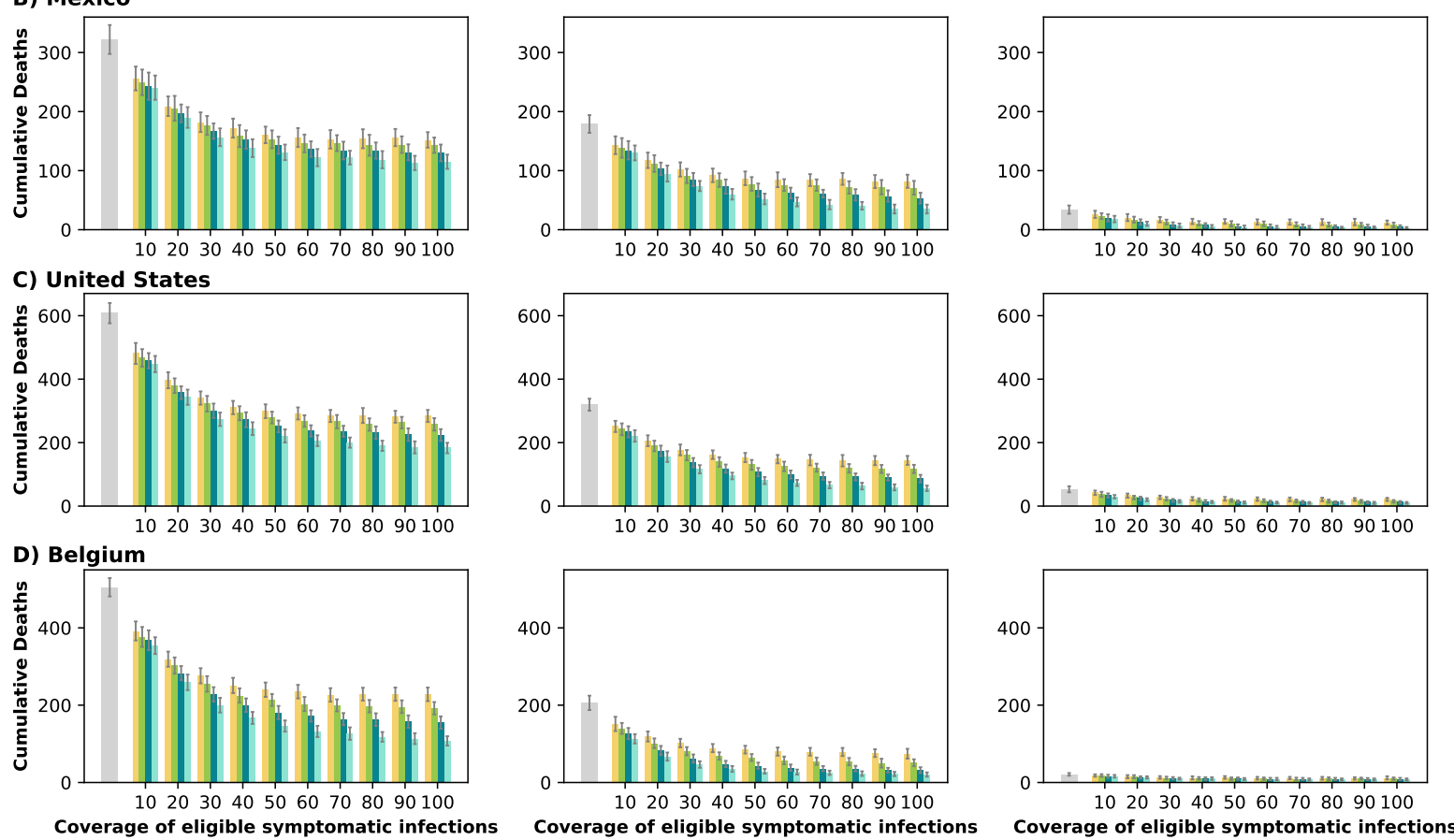

Figure S5: Cumulative deaths for A) Kenya, B) Mexico, C) United States and D) Belgium assuming 20 (left), 40 (middle) or $60 \%$ (right) of the population has been previously infected and is currently immune. For each country, we considered four possible values of $\operatorname{AVE}(25,50,75$ or $100 \%$ reduction in viral load) and covering $10-100 \%$ of eligible symptomatic individuals within the first 5 days of symptoms. Gray bars represent baseline cumulative deaths in absence of antiviral treatment. 
medRxiv preprint doi: https://doi.org/10.1101/2021.11.10.21266139; this version posted November 11, 2021. The copyright holder for this preprint (which was not certified by peer review) is the author/funder, who has granted medRxiv a license to display the preprint in perpetuity.

It is made available under a CC-BY-NC-ND 4.0 International license .
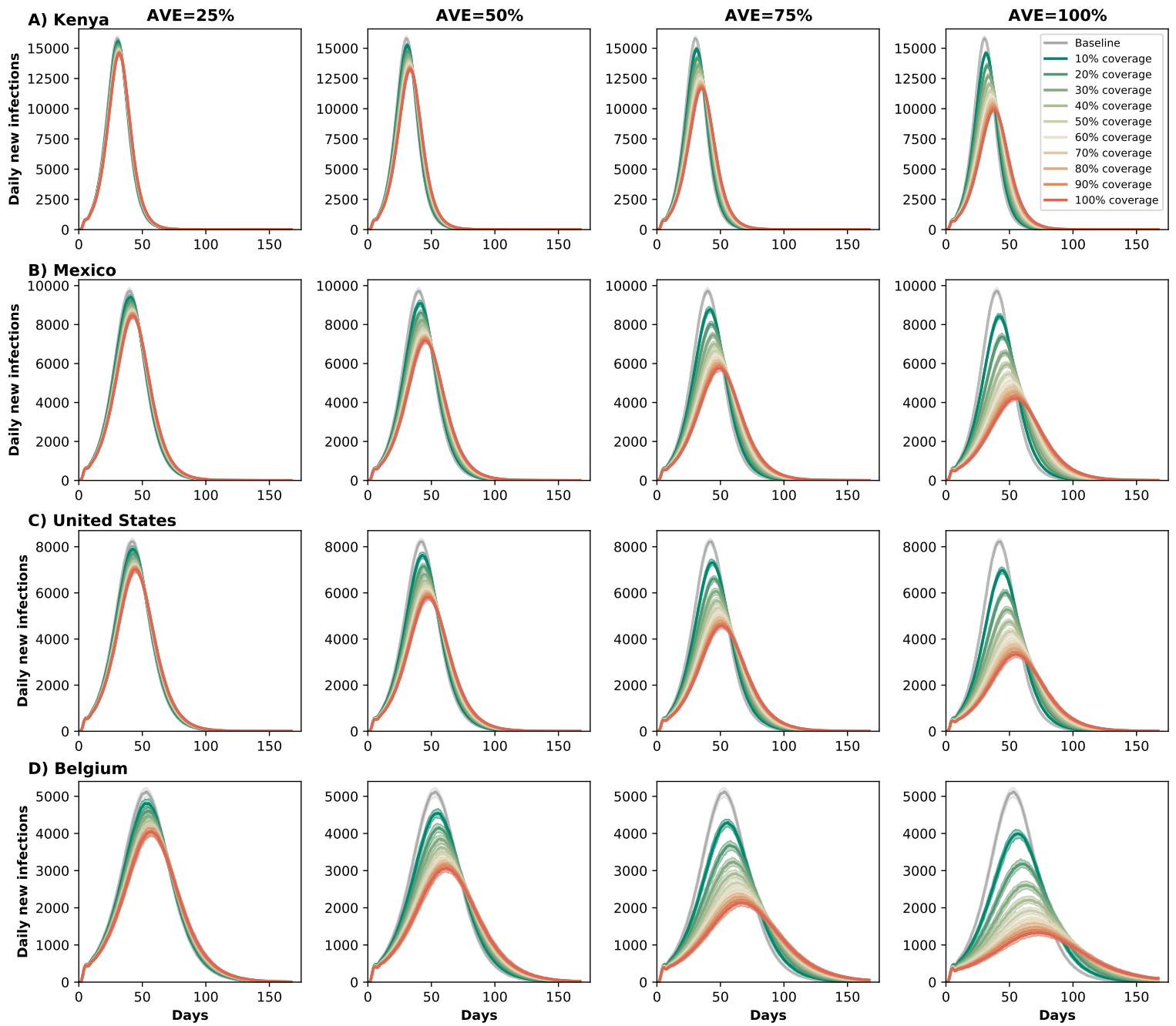

Figure S6: Daily new infections assuming no antiviral treatment (Baseline) or assuming coverage of 10-100\% of eligible symptomatic individuals in A) Kenya, B) Mexico, C) United States and D) Belgium assuming $20 \%$ of the population has been previously infected and is now recovered. For each country, each column represents a different value of AVE $(25,50$, 75 or $100 \%$ reduction in viral load). 
medRxiv preprint doi: https://doi.org/10.1101/2021.11.10.21266139; this version posted November 11, 2021. The copyright holder for this preprint (which was not certified by peer review) is the author/funder, who has granted medRxiv a license to display the preprint in perpetuity.

It is made available under a CC-BY-NC-ND 4.0 International license .
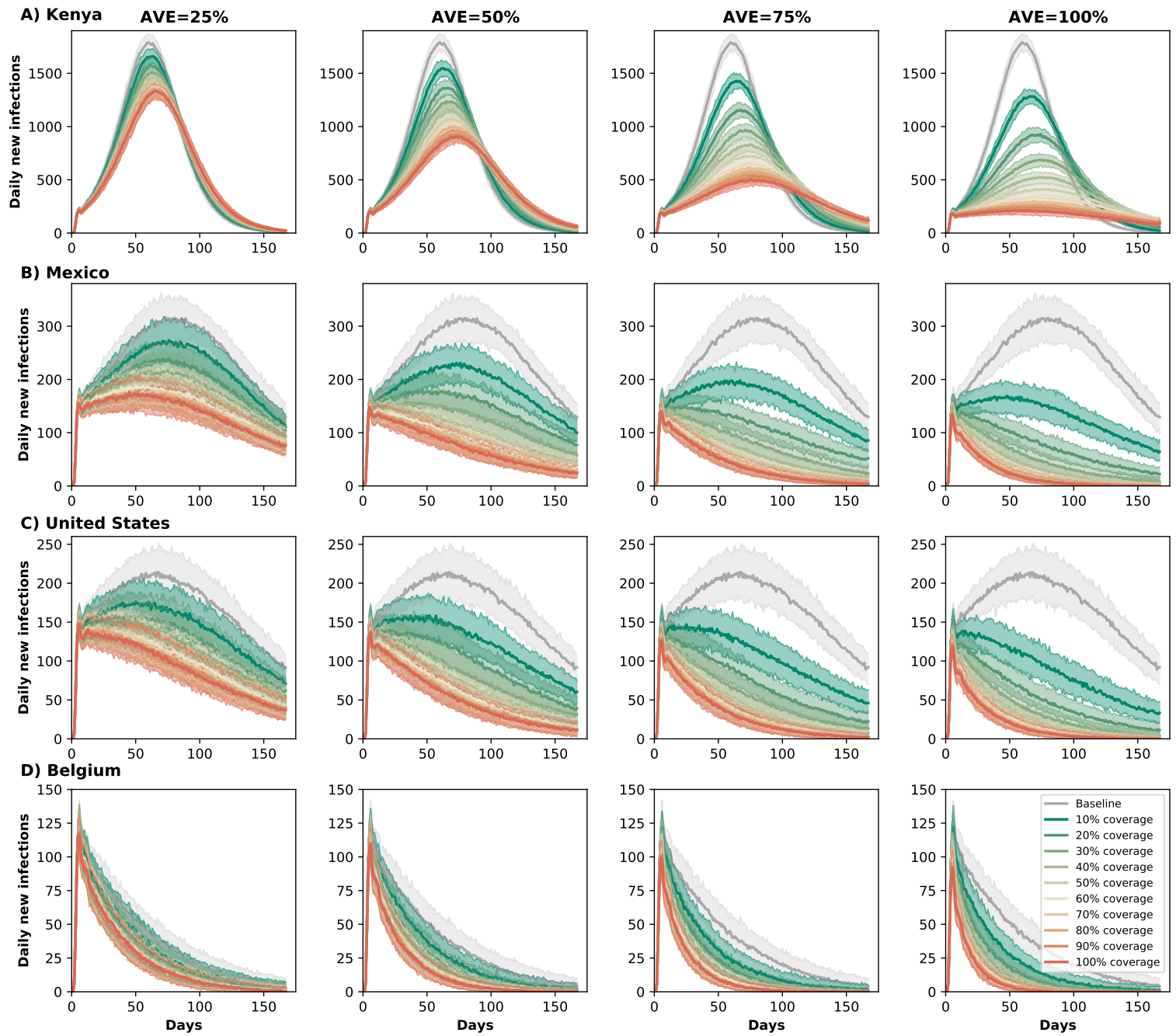

Figure S7: Daily new infections assuming no antiviral treatment (Baseline) or assuming coverage of 10-100\% of eligible symptomatic individuals in A) Kenya, B) Mexico, C) United States and D) Belgium assuming 60\% of the population has been previously infected and is now recovered. For each country, each column represents a different value of AVE (25, 50, 75 or $100 \%$ reduction in viral load). 
medRxiv preprint doi: https://doi.org/10.1101/2021.11.10.21266139; this version posted November 11, 2021. The copyright holder for this preprint (which was not certified by peer review) is the author/funder, who has granted medRxiv a license to display the preprint in perpetuity.

It is made available under a CC-BY-NC-ND 4.0 International license .
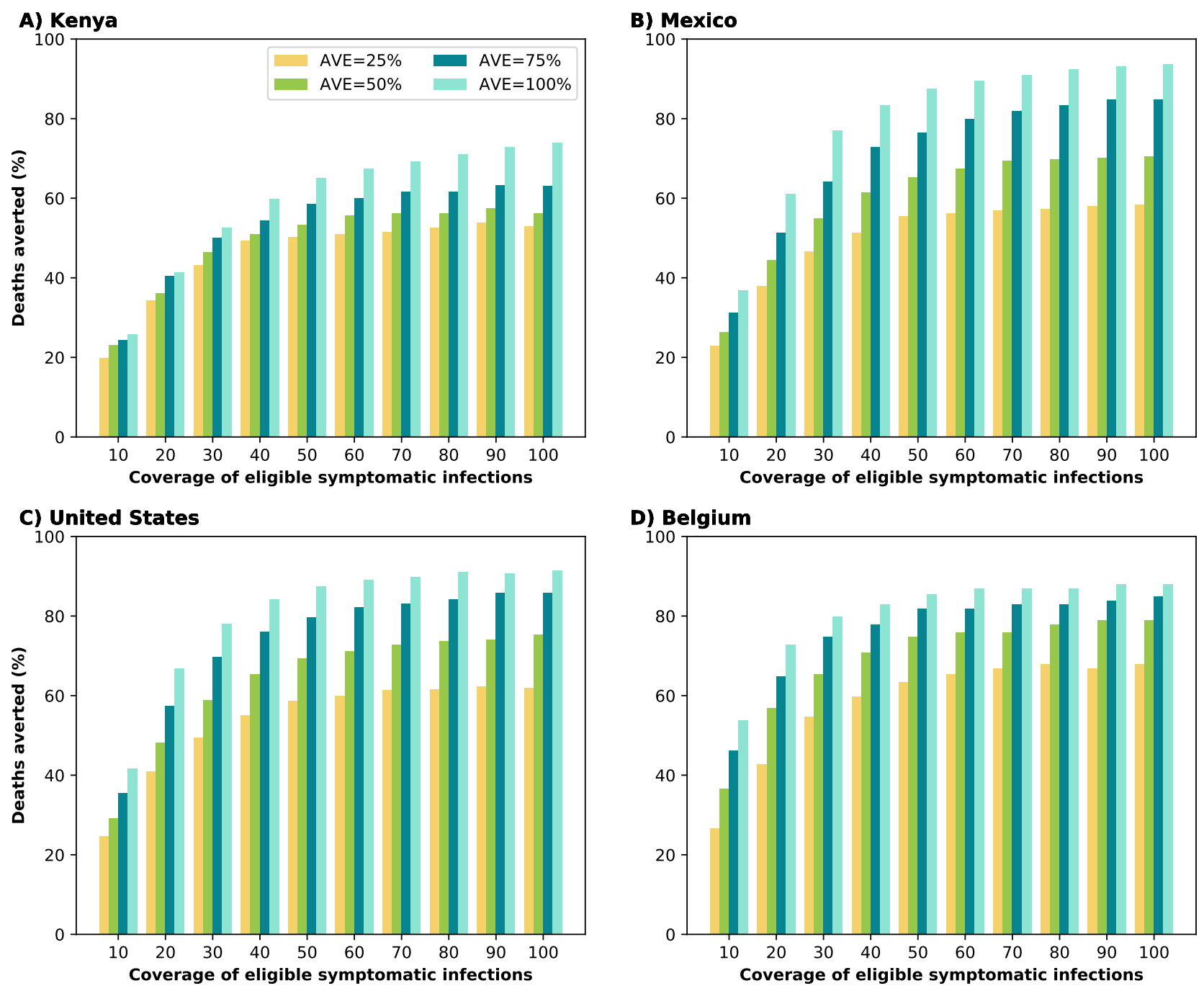

D) Belgium

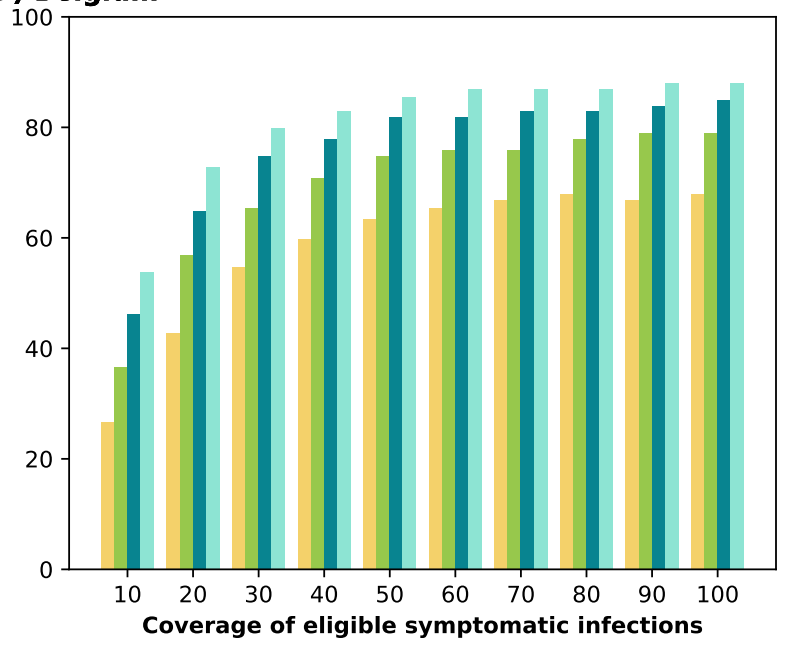

Figure S8: Percentage of deaths averted (compared to a baseline of no antiviral treatment) for A) Kenya, B) Mexico, C) United States and D) Belgium assuming asymptomatic infections are 50\% less infectious. For each country, we considered four possible values of $\operatorname{AVE}(25,50,75$ or $100 \%$ reduction in viral load) and covering 10-100\% of eligible symptomatic individuals within the first 5 days of symptoms. 